\title{
Jak stavby jihomoravských nádrží ovlivnily společenstva vodních a mokřadních rostlin
}

\section{ZDEŇKA ŽÁKOVÁ}

Klíčová slova: vodní a bažinné rostliny - řasová flóra - zátopová území nádrží - Brněnská přehrada Vranovská přehrada - vodní dílo Nové Mlýny

\section{SOUHRN}

V rámci řešení projektu Zatopené kulturní a přírodní dědictví jižní Moravy bylo shromážděno velké množství údajů o složení společenstev vodních a bažinných rostlin v řekách Svratce a Dyji před vybudováním Brněnské přehrady (1935-1940), Vranovské přehrady (1930-1933) a vodního díla Nové Mlýny (1975-1988). Vyhodnocení získaných údajů potvrdilo, že $v$ důsledku výstavby nádrží byla rostlinná společenstva v řece Svratce a v řece Dyji v zátopovém území nádrží i pod nádržemi silně ovlivněna.

Studie byla založena na srovnání údajů ze starších floristických prací se současným stavem flóry. V oblasti vodního díla Nové Mlýny studie vychází z extenzivního floristického výzkumu, prováděného před výstavbou nádrží. Řasová společenstva byla monitorována $v$ rámci projektů Výzkumného ústavu vodohospodářského T. G. Masaryka v Brně (v oblasti Brněnské přehrady v letech 1985 a 1992-1993, Vranovské prehrady po roce 1988 a v oblasti vodního díla Nové Mlýny od padesátých let minulého století) a dalších institucí (Povodí Moravy Brno, Botanického ústavu AV ČR aj.).

\section{ÚVOD}

\section{Brněnská přehrada}

V rámci projektu [1] jsme shromáždili velké množství podkladů o složení společenstev vodních a bažinných rostlin řeky Svratky před vybudováním Brněnské prehrady [2].

Vycházeli jsme ze starých floristických prací, hlavně autorů Nave [3] a Makowski [4], a dále z výsledků monitoringu brněnské pobočky Výzkumného ústavu vodohospodářského a Povodí Moravy Brno.

Řasová společenstva zátopového území Brněnské přehrady byla zkoumána již dlouho pred jejím vybudováním např. [3, 5-9]. V roce 1955 vydali autoři Lhotský a Rosa [10] Soupis Moravskoslezských sinic a řas, který zahrnoval i oblast Brněnské přehrady. Před vybudováním Brněnské přehrady - $v$ druhé polovině 19. století - Nave [3] prováděl průzkum, zaměřený na výskyt nárostových raas a sinic v zátopovém území. Johann Nave (1831-1864) byl jeden z nejvýznamnějších algologů Rakouska-Uherska, narozený v Praze, žijící v Brně, kde vystudoval gymnázium. Byl vystudovaný právník, ale věnoval se též s velkým zaujetím botanice - studiu řas. Založil v Brně přírodovědný spolek, ve kterém vydal práci Algen Mährens und Schleziens (Řasy Moravy a Slezska) v roce 1863. Při hodnocení podkladů o složení společenstev vyšších vodních a bažinných rostlin v zátopové oblasti řeky Svratky před vybudováním Brněnské přehrady jsme vycházeli ze starších floristických prací - hlavně z prací Alexandra Makowskiho (1882-1964) [4], který $\vee$ té době byl profesorem brněnské reálky, a Johanna Hrubého [11], německého botanika, působícího ve dvacátých letech minulého století v Brně. Spolkový časopis Verhandlungen des Naturforschenden Vereins in Brünn, který vycházel až do roku 1944, se stal hlavní publikační platformou brněnských, německy píšících floristů, a tedy i nejdůležitějším zdrojem údajů o květeně Brna v minulosti. Do 50. let 19. stol. spadá i začátek floristických aktivit Alexandra Makowskiho (1833-1908). Jeho Květena Brněnského kraje - Die Flora des Brünner Kreises [4], vyšla v prvním ročníku časopisu čerstvě založeného prírodovědeckého spolku (pojednáním o podnebí do ní přispěl i Gregor Johann Mendel) [12].

Jaký vliv mělo vybudování vodního díla na společenstvo řas a sinic, demonstrujeme na období posledních desetiletí, kdy se provádělo sledování za účelem zlepšování jakosti vody v Brněnské přehradě [11, 13-16].

\section{Vranovská přehrada}

Při hodnocení vlivu vybudování Vranovské přehrady na složení společenstev vodních a bažinných rostlin řeky Dyje jsme vycházeli ze starších publikovaných floristických prací a z výsledků monitoringu brněnské pobočky Výzkumného ústavu vodohospodárského T. G. Masaryka (dále Vúv Brno) a Povodí Moravy Brno. Potvrdilo se, že po vybudování přehrady byla zatopena hodnotná společenstva, obsahující velké množství ohrožených rostlin [17-19].

Pro znojemskou oblast včetně zátopového území Vranovské přehrady existují popisy flóry již z první poloviny 19. století [20-23]. Velmi důkladný fytogeografický průzkum oblasti Znojma a Retzu prováděli Wolfgang Himmelbaur z Vídně a Emil Stumme ze Znojma v letech 1914-1918 v době vojenské služby za podpory nestora moravských botaniků profesora Antona Oborného ze Znojma. Navzdory potížím poválečné doby (po první světové válce) se jim podařilo vytvořit dosti ucelený floristický obraz této oblasti [24]. Údaje o sledování řasové flóry $\vee$ zátopové oblasti Vranovské přehrady před jejím napuštěním (před rokem 1930) se nám nepodařilo získat. V této práci bylo proto hodnocení vlivu nádrže na řasovou flóru provedeno porovnáním řasových společenstev $\checkmark$ Dyji nad a pod Vranovskou přehradou z dostupných údajů brněnské pobočky Výzkumného ústavu vodohospodářského [25, 26] a Povodí Moravy Brno.

\section{Vodní dílo Nové Mlýny}

Jak vyplynulo ze shromážděných materiálů [27], bylo území vodního díla Nové Mlýny a její blízké či vzdálenější okolí v minulosti botanicky hojně studováno. Autoři Husák [28] a Heteša [29] uvádějí odkazy na práce odborníků, kteří tuto 
oblast zkoumali v minulosti [23, 30-42], i odborníky, kteří se zúčastnili organizovaného průzkumu před vybudováním nádrží v červenci 1977. Studiu jihomoravských mokřadních ekosystémů bylo věnováno rovněž mnoho práce a úsilí [43]. Soustavnější sběr dat o výskytu vláknitých řas v zátopové oblasti vodního díla Nové Mlýny a jeho okolí započal teprve v roce 1975. Byl podnícen potřebou doplnit mezery v celkovém obrazu řasové mikroflóry mizejících biotopů a současně požadavkem shromáždit podklady pro prognózu výskytu řas v nově vznikajících ekosystémech [44]. Sledování řasových společenstev volné vody (fytoplanktonu) řeky Dyje nad a pod soustavou nádrží Nové Mlýny, jednotlivých nádrží po jejich napuštění a jednotlivých př́toků prováděli systematicky pracovníci Výzkumného ústavu vodohospodářského T. G. Masaryka, pobočky Brno, od šedesátých let minulého století [45-50], a též pracovníci dalších institucí (Povodí Moravy Brno, Botanického ústavu AV ČR Třeboň aj.) [44, 51].

\section{VÝSLEDKY A DISKUSE}

\section{Brněnská přehrada}

\section{ZMĚNY SPOLEČENSTVA ŘAS A SINIC VE VODĚ (FYTOPLANKTONU)}

Změny množství řas a sinic ve vodě (fytoplanktonu) řeky Svratky pod Brněnskou přehradou jsou podmíněny procesy, probíhajícími v nádrži, režimem vypouštění vody, popř. opatřeními, prováděnými v nádrži pro zlepšení jakosti vody.

Brněnská přehrada byla v posledních desetiletích zatěžována vysokými koncentracemi biogenních prvků (dusík, fosfor), přitékajících z povodí řeky Svratky nad přehradou v důsledku nadměrné eutrofizace povodí. Se stoupajícím prísunem živin se začal ve vodě vyskytovat sinicový vodní květ, který svou schopností uvolňovat toxiny, může být nebezpečný pro koupající se lidi. Z hlediska rekreačního využití prehehrady to byl vážný problém, přetrvávající do dnešních dnů. Brněnská přehrada patřila k povrchovým vodám s pravidelným masovým rozvojem sinicového vodního květu, ve kterém převládal rod Microcystis (obr. 1) [13-15].

Silný výskyt této sinice jsme zaznamenali již v roce 1985 při nesystematických rozborech, prováděných Vúv Brno - nepublikované rozbory z archivu Žákové. $\checkmark$ roce 1993 jsme sledovali rozvoj fytoplanktonu $v$ průběhu celé vegetační sezony od dubna do řijna [16]. Zachytili jsme průběh rozvoje vodního květu, tvořeného převážně druhem Microcystis aeruginosa, v menším množství dalšími druhy sinic (Aphanizomenon flos-aquae, Planktothrix agardhii aj.). V době vegetačního maxima v červenci jsme zjistili 2500 kolonií Microcystis aeruginosa (o prům. $200 \mu$ ) v $1 \mathrm{ml}$ vody $\vee$ hladinové vrstvě u hráze. $\vee$ dalších letech se situace dále postupně zhoršovala.

Rok 2006 charakterizuje stav před zahájením ozdravných opatření v nádrži, kde se ve vegetačním období silně rozmnožoval fytoplankton a zejména sinice, produkující toxiny. Tím bylo v letním období úplně znemožněno koupání. Velké množství řas a sinic odtékalo do Svratky. Od roku 2007 byla prováděna v Brněnské přehradě opatření proti sinicovým vodním květům - razantní snížení hladiny (prakticky přestala údolní přehrada existovat a změnila se ve velkou silně zpomalenou řeku, popř. v nádrž s extrémně krátkou dobou zdržení). Letecké ošetření obnaženého dna vápenným hydrátem proběhlo na podzim roku 2007, v únoru a listopadu 2008 a poslední v dubnu 2009. Dále bylo zahájeno dávkování chemikálií - vápna ve formě vápenného hydrátu a síranu železitého na přitoku do nádrže pro srážení fosforu. Dávkování PIXu 113 (což je obchodní název pro 41\% roztok síranu železitého) na vtoku do nádrže mělo za cíl vysrážet fosfor pritékající do nádrže z povodí nad nádrží. Prostřednictvím nízké dávky síranu železitého poklesla koncentrace fosforečnanů až o $96 \%$. Dále bylo zahájeno provzdušňování hypolimnia, kterým se zajištuje oxidace sedimentů, a tím omezený přestup živin do vodního sloupce. Provzdušňování je realizováno pomocí kyslíkových věží [14, 52]. Prvořadým posláním provzdušňování vody v Brněnské přehradě je snaha znevýhodnit podmínky pro život sinic (narušit shromažd’ování těchto organismů s plynovými měchýřky při hladině), a tím tedy podpořit rozvoj jiných fototrofů - zelených ras, rozsivek apod. (podle Marvana - ústní sdělení).

Po zavedení těchto opatření se stav postupně zlepšoval [13, 14]. V období 2010-2012 v letním období na vrcholu vegetační sezony ani jednou nedosáhly objemové dominance sinice rodu Microcystis. Byly nahrazeny skupinami jiných sinic a řas, které nezpůsobují zdravotní, organoleptické ani estetické závady zadržované vody, jak tomu bývá u vodního květu (např. druhy Fragilaria crotonensis obr. 2, Asterionella formosa - obr. 3, Stephanodiscus hantzschii, Aulacoseira granulata, Cyclostephanos dubius, C. invisitatus, Cyclotella pseudostelligera, Fragilaria acus, Nitzschia spp., Cryptomonas spp, Ceratium spp., Coelastrum spp., Pediastrum spp., Desmodesmus sp., Scenedesmus spp. aj.).

Změny rozvoje fytoplanktonu v nádrži se odrážely ve složení společenstev volné vody i ve Svratce pod nádrží.

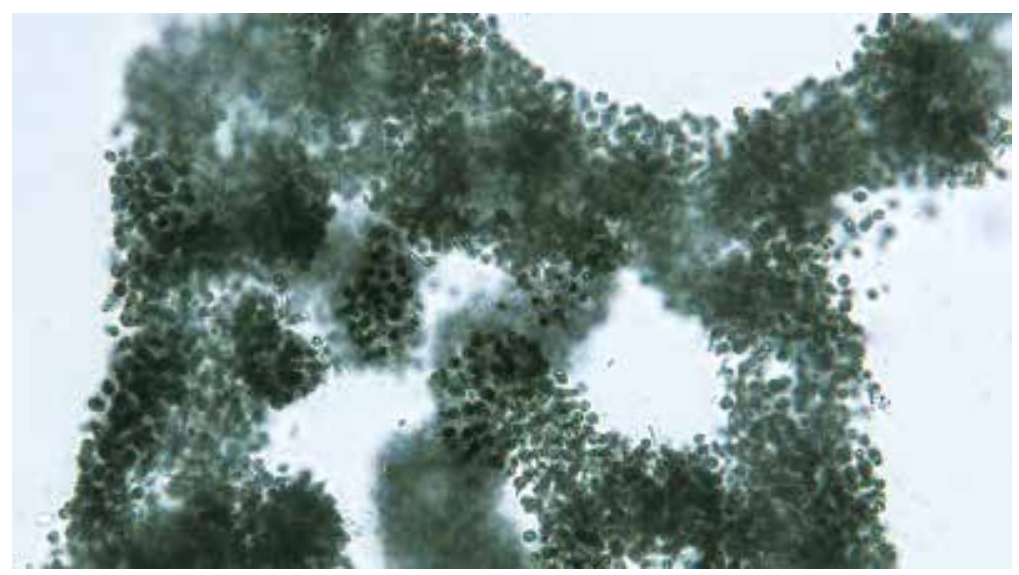

Obr. 1. Microcystis aeruginosa - nejtypičtější složka vodního květu Brněnské přehrady před nápravnými opatřeními (fotografie: R. Geriš [13])

Fig. 1. Microcystis aeruginosa - major component of water bloom in the Brno Dam before corrective actions (photo: R. Geriš [13])

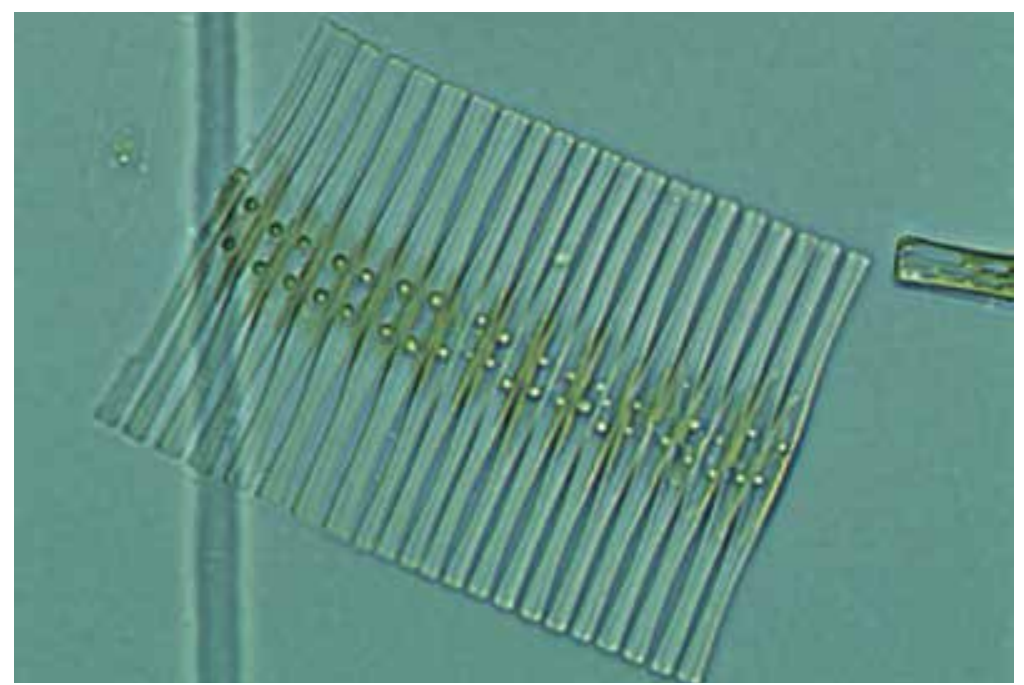

Obr. 2. Fragilaria crotonensis - typický zástupce fytoplanktonu po nápravných opatřeních $\checkmark$ Brněnské přehradě (fotografie: P. Sedláček)

Fig. 2. Fragilaria crotonensis typical representant of phytoplankton in the Brno Dam after corrective actions (photo: P. Sedláček) 


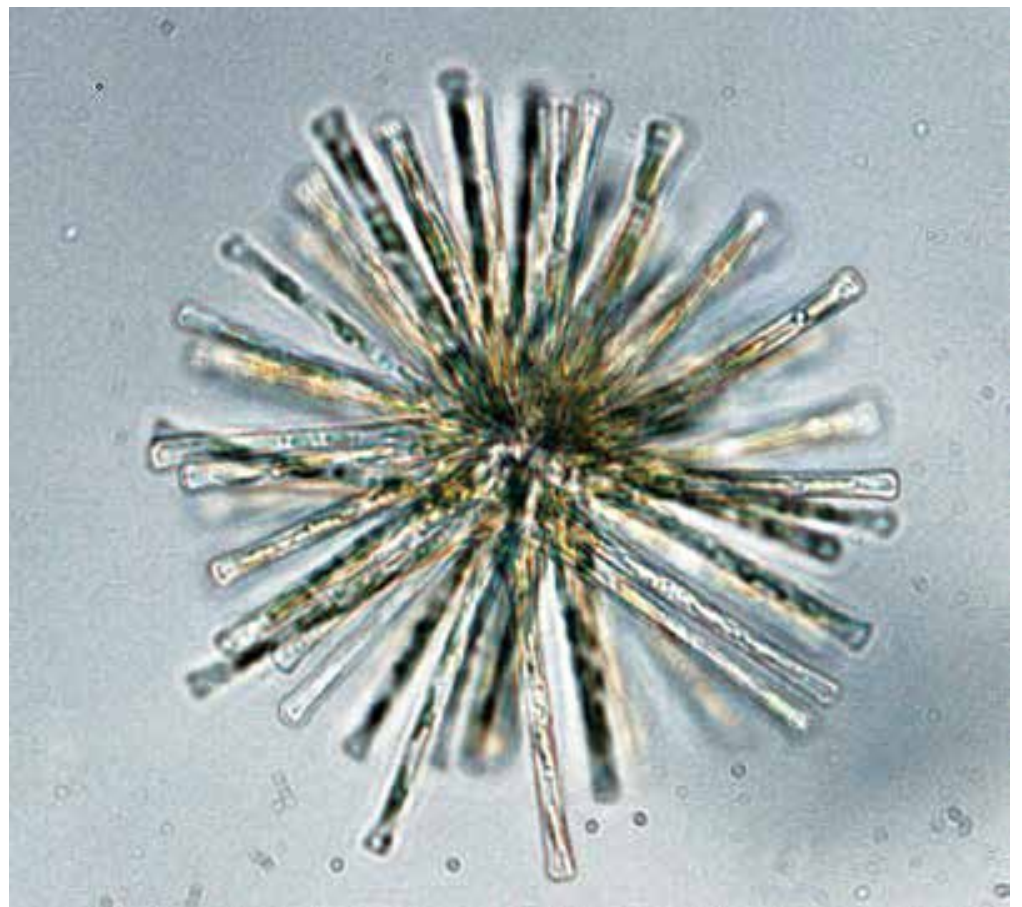

Obr. 3. Asterionella formosa - další typický zástupce fytoplanktonu po nápravných opatreních v Brněnské přehradě (fotografie: R. Geriš)

Fig. 3. Asterionella formosa - another typical representant of phytoplankton in the Brno Dam after corrective actions (photo: R. Geriš)

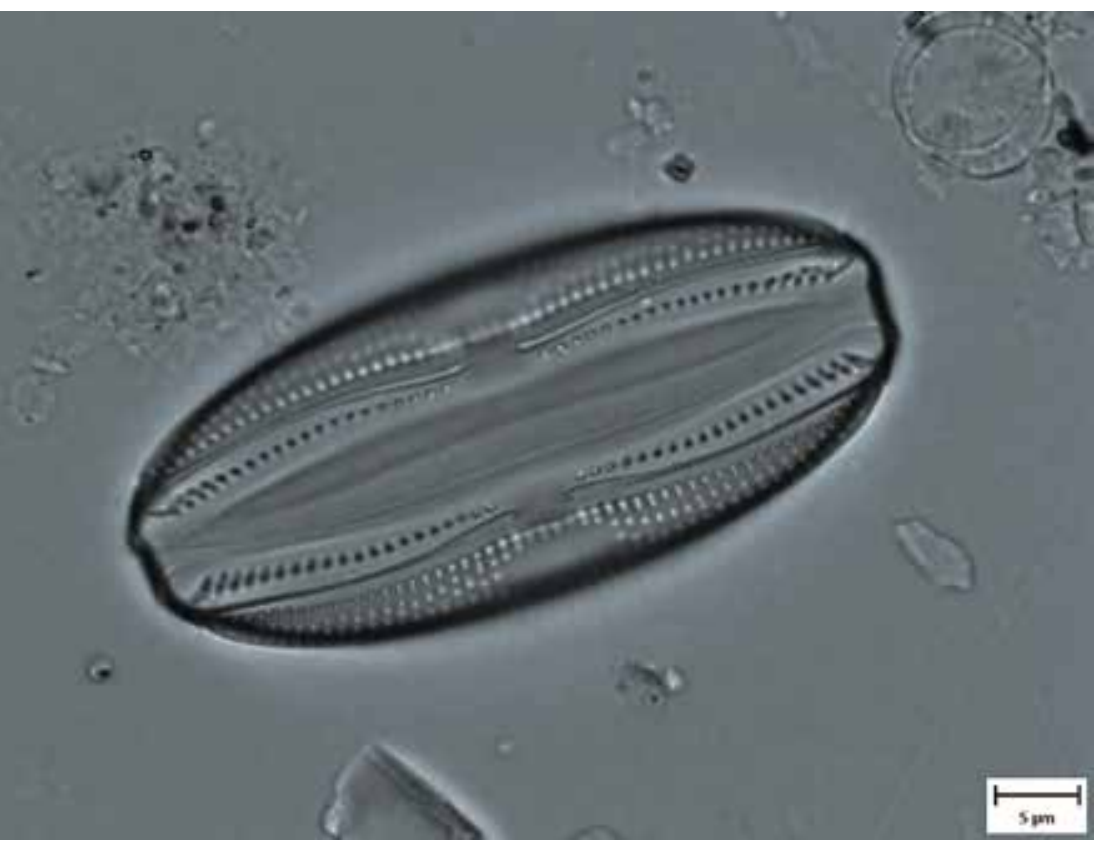

Obr. 4. Amphora ovalis - nárostová rozsivka, jejiž výskyt pozoroval v zátopové oblasti Nave již v době před vybudováním Brněnské přehrady (fotografie: P. Sedláček) Fig. 4. Amphora ovalis - periphytic diatom, observed by Nave in the flooded area before construction of the Brno Dam (photo: P. Sedláček)

\section{ZMĚNY SPOLEČENSTVA ŘASOVÝCH A SINICOVÝCH} NÁROSTU゚ DNA (FYTOBENTOSU)

Nave [3] uváděl ve Svratce $v$ zátopové oblasti Brněnské přehrady v nárostech na dně a ponořených předmětech druhově pestré společenstvo řas ( $v$ hranaté závorce současně používané názvy):

Epithemia zebra (Ehbg.), Epithemia sorex Kg., Ceratoneis amphioxys Rabenh. [Hannea arcus], Encyonema prostratum Ralfs, Achnanthes minutissima Kg. [Achnanthidium minutissimum], Cymatopleura solea Bréb., Amphora ovalis (Ehrenb.) Kg. (obr. 4), Navicula borealis Kg. f. robusta, Navicula anglica Ralfs, Navicula rhynchocephala Kg., Navicula amphisbaena Kg. [Caloneis amphisbaena], Navicula inflata Kg., Navicula dicephala, Kg., Navicula producta, W.Sm [Neidium productum], Navicula affinis, Ehrenb [Neidium affine], Navicula exilis Kg. [Anomoeoneis exilis], Pleurosigma scalproides Rabh. [Gyrosigma scalproides], Pleurosigma Spenceri W.Sm., Synedra bilunaris Kg., Synedra ulna Ehrb., Synedra amphirhynchus Ehrenb., Nitzschia sigmoidea W.Sm., Nitzschia vermicularis Kg., Nitzschia tenuis W.Sm., Sphenella angustata Kg [Gomphonema angustatum], Gomphonema micropus Kg., Characium acutum A.Br. [Characiopsis acuta], Pediastrum boryanum (Turp.) Menegh., Palmogloea macrococca A.Br., Closterium moniliferum Ehrenb., Cosmarium Meneghinii Bréb., Spirogyra communis Kg., Spirogyra jugalis Kg., Spirogyra setiformis (Roth.) Kg., Confervabombycina Ag., Cladophora lacustris Kg. [Cladophora globulina], Oedogonium capillare Kg., Chara foetida A.Br.

Nejhojnějši řasy a sinice na dně řeky Svratky nad Brněnskou přehradou (Veverská Bítýška) v letech 1991 a 2005 (nesoustavné rozbory Žakové - VúV Brno): - Rozsivky (Bacillariophyceae): Melosira varians, Cymbella ventricosa [Encyonema ventricosum], Navicula cryptocephala, Navicula avenacea, Navicula gracilis [Navicula tripunctata], Rhoicosphenia curvata [Rhoicospenia abbreviata], 2005 navíc Diatoma vulgaris,

- Ulotrichales: Stigeoclonium tenue (obr. 5), Siphonocladiales: Cladophora glomerata,

- Chlorococcales: Scenedesmus bicaudatus [Desmodesmus bicaudatus], Scenedesmus obliquus; 2005 - Scenedesmus quadricauda [Desmoesmus quadricauda],

- Rhodophyta:2005 - Audouinella chalybaea.

Nejhojnější řasy a sinice $v$ nárostech na dně ve Svratce pod Brněnskou přehradou (Pisárky) v roce 1991 (podle rozborů Žákové - Vúv Brno):

- Sinice (Cyanobacteria): Oscillatoria sp. div.

- Rozsivky (Bacillariophyceae): Cocconeis pediculus, Melosira varians, Navicula cryptocephala, Nitzschia sp., Rhoicosphenia curvata [Rhoicospenia abbreviata],

- Xanthophyceae: Vaucheria sp.,

- Ulotrichales: Oedogonium sp.

- Siphonocladiales: Cladophora glomerata

- Chlorococcales: Monoraphidium arcuatum, Monoraphidium contortum, Scenedesmus sp. div. [Desmodesmus sp. div.] aj.

Podle složení společenstva fytobentosu (nárostů) byla voda ve Svratce nad Brněnskou přehradou hodnocena jako mírně znečištěná, stav fytobentosu pod přehradou byl sledován ve větší vzdálenosti, která neumožňuje spolehlivé hodnocení vlivu přehrady.

\section{ZMĚNY SPOLEČENSTVA VYŠŠíCH VODNÍCH A BAŽINNÝCH ROSTLIN}

V zátopové oblasti Brněnské přehrady byl zaznamenán výskyt více než 50 druhů vodních a bažinných rostlin, které zmizely pod hladinou nádrže. Vyskytoval se zde větší počet ohrožených druhů, uvedených v Červeném seznamu cévnatých rostlin České republiky jako druhy kriticky ohrožené až po druhy vyžadující zvýšenou ochranu [53].

Makowski [4] uváděl v zátopové oblasti Brněnské přehrady a širším povodí Svratky výskyt těchto druhů vodních a bažinných rostlin (v hranaté závorce současné názvy podle Kubáta [54]): 


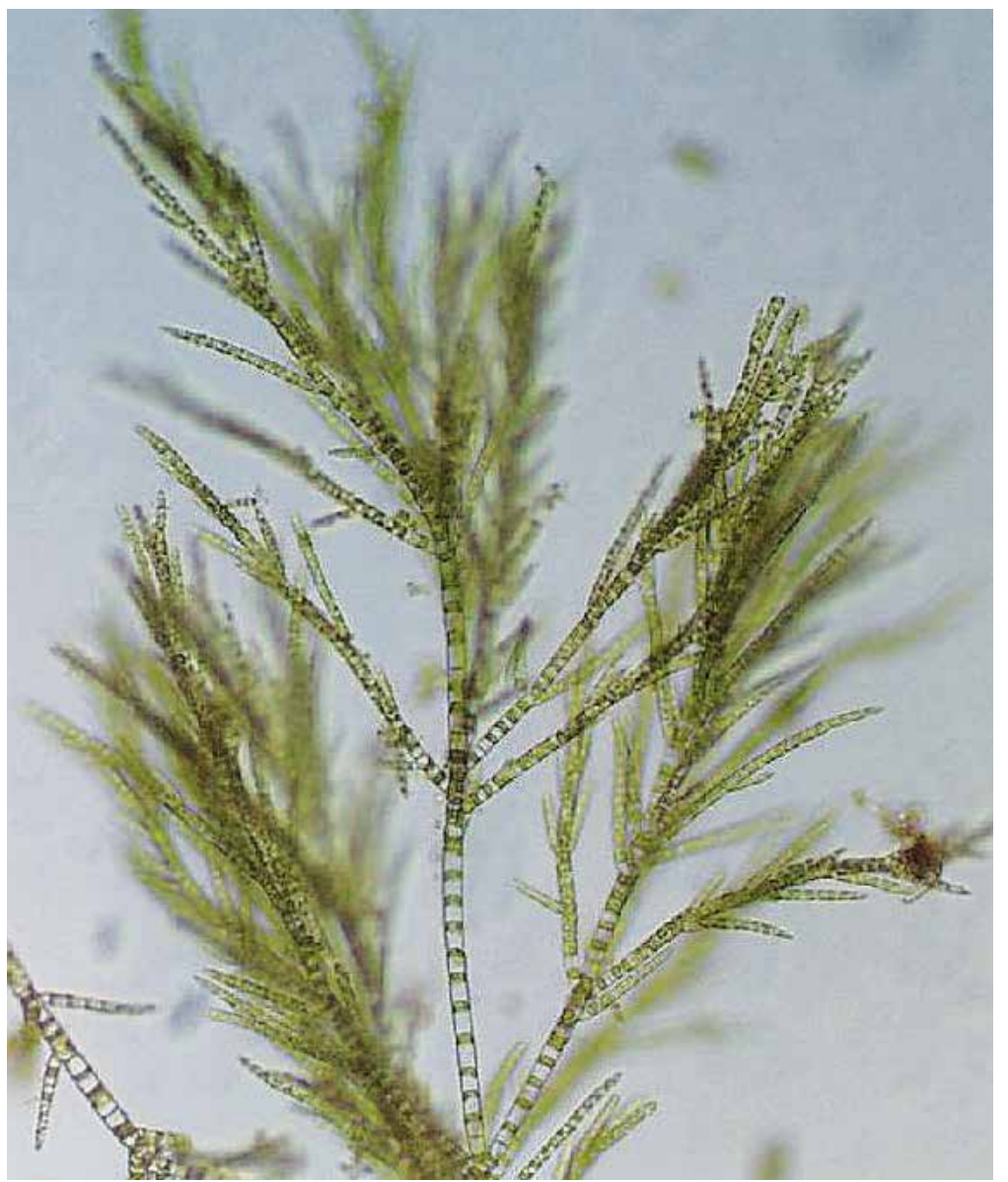

Obr. 5. Stigeoclonium tenue (C. Agardh) Kütz - typická vláknitá řasa v řece Svratce nad Brněnskou přehradou (fotografie: J. Kaštovský)

Fig. 5. Stigeoclonium tenue (C. Agardh) Kütz - typical filamentous benthic alga in the Svratka River upstream of the Brno Dam (photo: J. Kaštovský)

\section{A. MONOCOTYLEDONAE (JEDNODĚLOŽNÉ ROSTLINY):}

Glyceria fluitans R.Br., Glyceria aquatica Presl. [G. maxima] (obr. 6), Phragmites communis Trin. [P. australis], Carex vulpina L., Carex remota L. (u hradu Veveří), Carex acuta L., Carex riparia Curt., Carex pseudocyperus L., Carex vesicaria L., Scirpus setaceus L. [Isolepis setacea], Scirpus lacustris L. [Schoenoplectus lacustris], Scirpus acicularis L.[Eleocharis acicularis], Scirpus compressus Pers., Scirpus maritimus L. [Bolboschoenus maritimus], Cyperus fuscus L., Iris pseudacorus L., Potamogeton natans L., Potamogeton lucens L., Potamogeton crispus L., Potamogeton pusillus L., Lemna polyrrhiza L. [Spirodela polyrhiza], Lemna gibba L., Lemna minor L., Lemna trisulca L., Acorus calamus L., Typha latifolia L., Typha angustifolia L. (obr. 7), Sparganium ramosum Huds. [S. erectum], Sparganium simplex Huds.[S. emersum].

\section{B. DICOTYLEDONEAE (DVOJDĚLOŽNÉ ROSTLINY):}

Ceratophyllum demersum L., Callitriche verna L. [C. palustris], Rumex maritimus L., Polygonum amphibium L., Polygonum lapathifolium L., Bidens cernua Huds., Senecio crispus Neil. syn. rivularis, Mentha aquatica L., Limosella aquatica L., Veronica anagallis L., Veronica beccabunga L., Ranunculus aquatilis L., Ranunculus divaricatus Schrank.[Batrachium trichophyllum], Caltha palustris, L., Roripa amphibia Bess., Elatine triandra Schk., Epilobium parviflorum Schreb., Myriophyllum spicatum L., Lythrum salicaria $L$.
Většina uvedených rostlin po napuštění nádrže vymizela. Mezi nimi byl i větší počet chráněných rostlin (např. Potamogeton lucens L., Carex riparia Curt., Veronica anagallis $L$., Ranunculus aquatilis $L$.). Některé $v$ seznamu uvedené druhy přežívají na březích nádrže (např. Iris pseudacorus L., Lythrum salicaria L.), jiné vytvářejí semennou banku se životností několika let a po snižení hladiny se mohou rozmnožit ve velkém množství (např. Carex pseudocyperus L., Cyperus fuscus L., Veronica anagallis L.).

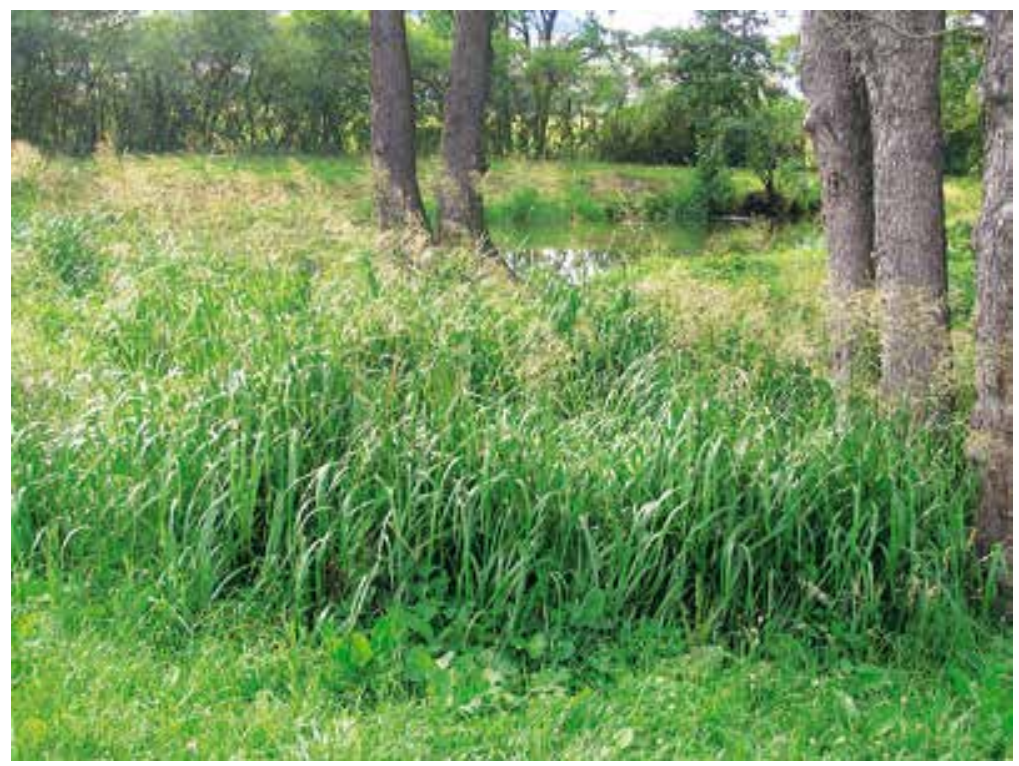

Obr. 6. Zblochan vodní Glyceria aquatica Presl. [G. maxima] - hojný druh vyšších vodních rostlin v řece Svratce před vybudováním Brněnské přehrady

Fig. 6. Glyceria aquatica Presl. [G. maxima] abundant plant species of marshes in the Svratka River before construction of the Brno Dam

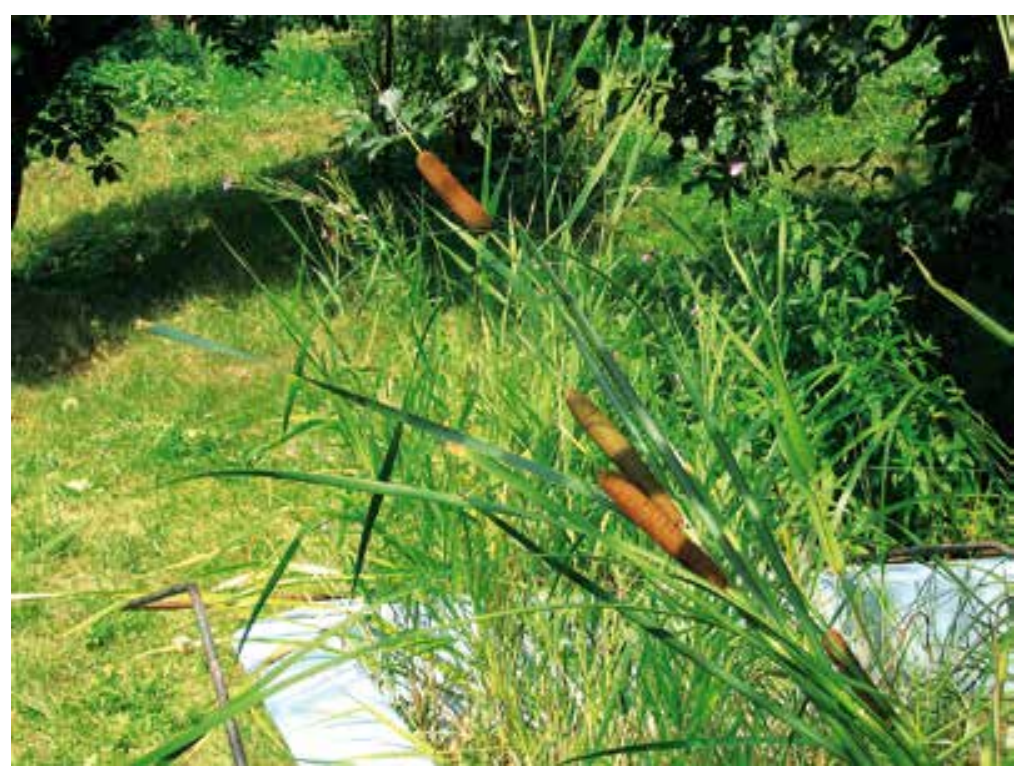

Obr. 7. Orobinec úzkolistý Typha angustifolia L. - druh vyšších vodních rostlin v řece Svratce před vybudováním Brněnské přehrady

Fig. 7. Typha angustifolia L. - plant species of marshes in the Svratka River before construction of the Brno Dam 


\section{Vranovská přehrada}

\section{ZMĚNY SPOLEČENSTVA ŘAS A SINIC \\ VE VODĚ (FYTOPLANKTONU)}

Vranovská přehrada je hluboká nádrž, korytovitého tvaru, která zachycuje téměř úplně přinášený i vyprodukovaný fytoplankton (působí jako účinný lapač fytoplanktonu). Je to zřejmé z dlouhodobého znázornění koncentrace chlorofylu-a ve vodě, který je neprímým měřítkem množství řas a sinic ve vodě (obr. 8). Z porovnání obsahu chlorofylu-a v řece Dyji nad a pod Vranovskou přehradou je ž̌ejmé, že nad přehradou Dyje obsahuje ve vegetačním období velké množství fytoplanktonu, který zůstává zachycen v nádrži, takže pod nádrží je množství fytoplanktonu většinou zanedbatelné.

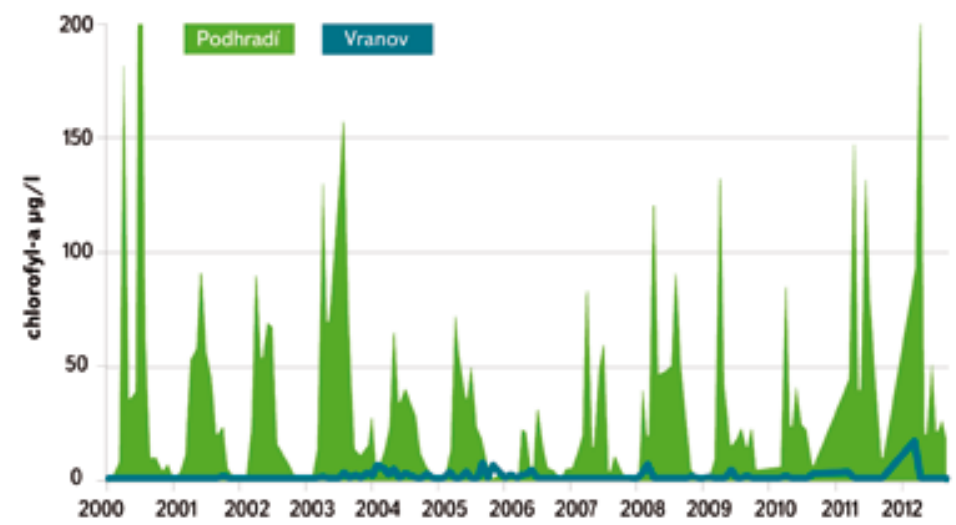

Obr. 8. Změny množství fytoplanktonu (chlorofylu-a) v řece Dyji nad a pod Vranovskou přehradou v letech 2000-2012 (data: PM Brno)

Fig. 8. Variation of phytoplankton abundance (Chlorophyll-a) in the Dyje River upstream and downstream of the Vranov Dam (2000-2012) (data: PM Brno)

Řeka Dyje nad Vranovskou přehradou se vyznačuje vysokou druhovou diverzitou společenstva fytoplanktonu. $\vee$ roce 2010 bylo $v$ Dyji nad přehradou identifikováno celkem 193 taxonů řas a sinic. Pod přehradou se počet druhů výrazně snižuje.

\section{ZMĚNY SPOLEČENSTVA ŘASOVÝCH NÁROSTŮ DNA (FYTOBENTOSU)}

Druhová pestrost společenstva nárostových řas a sinic (fytobentosu) je v Dyji nad Vranovskou přehradou vysoká (v roce 2010 bylo v Dyji v Drosendorfu identifikováno přes 86 druhů). Pod nádrží se počet druhů snižuje (zjištěno maximálně něco přes 20 druhů), ale v následném úseku až po profil Devět Mlýnů se opět zvyšuje (zjištěno 93 druhů).

Nad nádrží Vranov v profilu Podhradí ve fytobentosu v roce 1992 převládaly zelené řasy (Chlorophyceae), zastoupené převážně vláknitými řasami Cladophora glomerata a Oedogonium sp. spolu s pestrým společenstvem chlorokokálních řas s převahou druhů rodu Scenedesmus [Desmodesmus] a dále rozsivky (Bacillariophyceae) s dominantními druhy Aulacoseira subarctica, Melosira varians, Fragilaria ulna a druhy rodu Navicula. Byl zjištěn i výskyt ruduchy (Rhodophyta) Lemanea fluviatilis (obr. 9). V nárostech v řece Dyji pod nádrží Vranov ve stejném roce (1992) se ve velkém množství vyskytovaly vláknité sinice rodu Phormidium a druhově chudé společenstvo rozsivek (Bacillariophyceae) bez výrazné dominance některého druhu. Vyskytovaly se zde též silné porosty vláknitých řas rodů Spirogyra (obr. 10), Ulothrix, Rhizoclonium a v menším množství rodu Vaucheria.

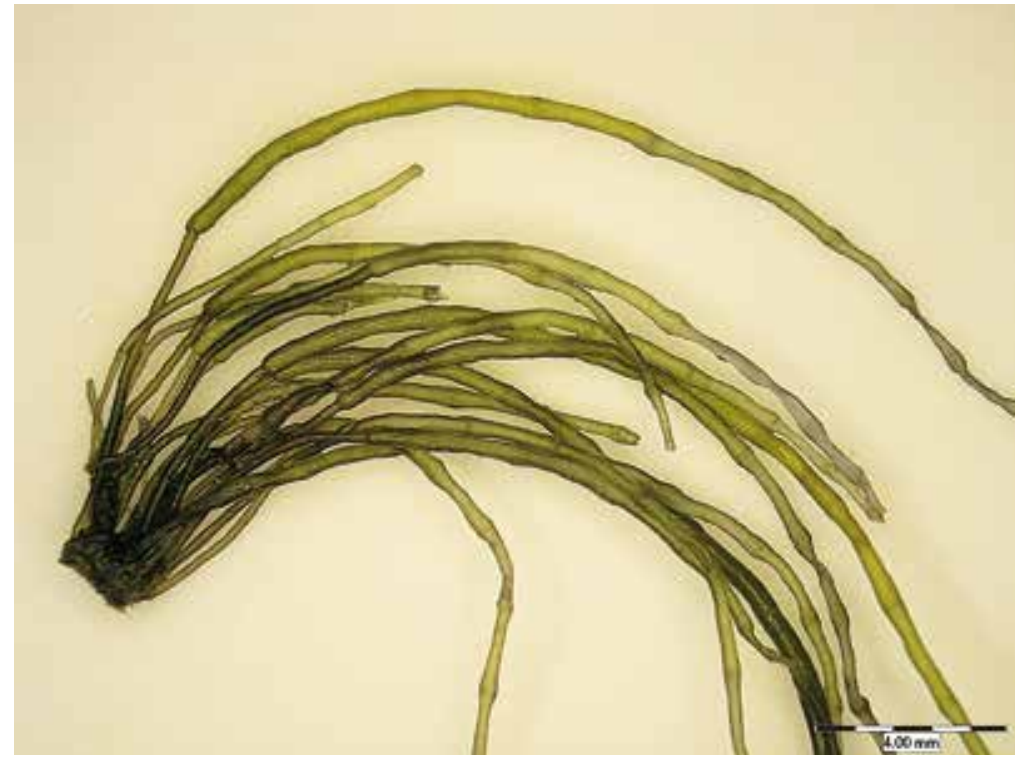

Obr. 9. Lemanea fluviatilis (Linnaeus) C. Agardh vzácná bentická ruducha v řece Dyji nad Vranovskou přehradou (fotografie: J. Kaštovský)

Fig. 9. Lemanea fluviatilis - a rare filamentous benthic alga (Rhodopyta) in the Dyje River upstream of the Vranov Dam (photo: J. Kaštovský)

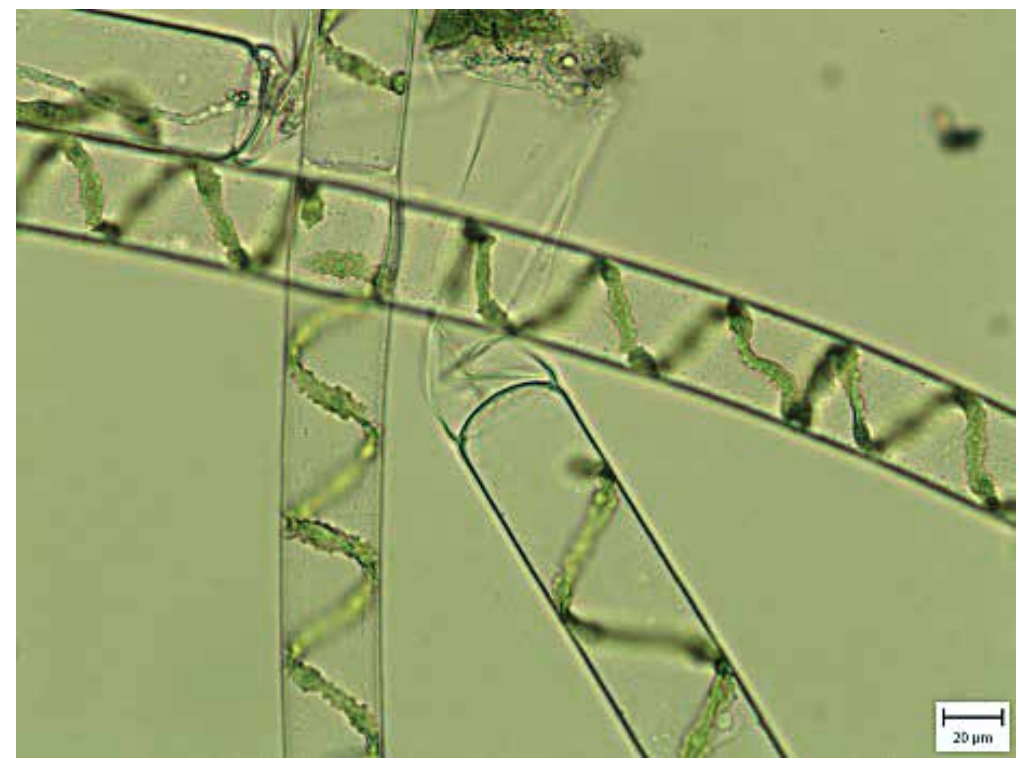

Obr. 10. Vláknitá řasa šroubatka Spirogyra sp. v nárostech v Dyji pod Vranovskou přehradou (fotografie: P. Sedláček)

Fig. 10. Filamentous alga Spirogyra sp. in periphyton of the Dyje River below the Vranov Dam (photo: P. Sedláček)

Vranovská přehrada po většinu roku eliminuje nepř́znivé vlivy horního povodí Dyje - přinášené organické znečištění a fytoplankton. Na složení společenstev nárostů v řece Dyji pod nádrží se také projevuje vliv energetického provozu špičkové vodní elektrárny Vranov [55]. Složení řasových nárostů (fytobentosu) v Dyji pod Vranovskou přehradou charakterizovalo Dyji v roce 2000 jako mírně znečištěný tok. 


\section{ZMĚNY SPOLEČENSTVA VYŠŠíCH VODNÍCH}

\section{A BAŽINNÝCH ROSTLIN}

Autoři Himmelbaur a Stumme [24] publikovali přehled flóry oblasti Znojma a Retzu, ve kterém byly zahrnuty též významné druhy vodních a bažinných rostlin $v$ zátopové oblasti nádrže Vranov před jejím napuštěním ( $v$ závorce druhy vyskytující se řídce až ojediněle). $V$ prehledu je znázorněno porovnání se stavem, zjištěným pod Vranovskou nádrží v roce 2008 [56] - podtržené druhy. Dále jsou tučně zvýrazněny ohrožené druhy podle Červeného seznamu cévnatých rostlin České republiky [55] a v hranatých závorkách jsou současné názvy podle Kubáta [54]:

\section{VODNÍ ROSTLINY (STŘEDOEVROPSKÁ KVĚTENA)}

Potamogeton natans - rdest plovoucí, (Potamogeton lucens - rdest světlý) Potamogeton crispus - rdest kadeřavý, (Potamogeton pectinatus - rdest hřebenitý), (Potamogeton pusillus - rdest maličký), (Sagittaria sagittifolia šípatka střelolistá), Alisma plantago [aquatica] - žabník jitrocelový, (Butomus umbellatus - šmel okoličnatý), (Hydrocharis morsus ranae - vod'anka žabí), Spirodela polyrhiza - závitka mnohokořenná, (Lemna trisulca - okřehek trojbrázdý), Lemna minor - okřehek menší, (Lemna gibba - okřehek hrbatý), Polygonum amphibium syn. Persicaria amphibia - rdesno obojživelné (Nuphar luteum [N. lutea] - stulík žlutý), (Castalia candida [Nymphaea candida] - leknín bělostný), (Ceratophyllum demersum - růžkatec ponořený), (Ranunculus aquatilis [Batrachium aquatile] - lakušník vodní), (Ranunculus circinatus [Batrachium circinatum] - lakušník okrouhlý), Ranunculus [Batrachium] fluitans - lakušník vzplývavý, (Ranunculus trichophyllus [Batrachium] trichophyllum - lakušník vláskolistý [nitolistý], (Callitriche platycarpa - hvězdoš mnohotvárný [hranoplodý]) Callitriche verna [C. palustris] - hvězdoš jarní, (Callitriche hamulata - hvězdoš háčkatý), (Myriophyllum verticillatum - stolístek přeslenitý), Myriophyllum spicatum - stolístek klasnatý, (Hippuris vulgaris - prustka obecná), (Utricularia vulgaris - bublinatka obecná)

Toto společenstvo nebylo v peřejnatých úsecích, protékajících úzkými údolími se strmými svahy príliš hojné. Jen v klidných mělkých úsecích toku a na klidných okrajích říčního koryta se uchytily porosty vodních rostlin.

\section{BAŽINNÉ ROSTLINY}

Glyceria aqutica [G.maxima]* - zblochan vodní, (Holoschoenus vulgaris* kamýšek římský, [Scirpoides holoschoenus - kamýšek obecný]), (Carexpseudocyperus-ostřicenedošáchor, Carexriparia-ostřice pobřežní,Carexdisticha-ostřice dvouřadá), (Juncus atratus** - sítina tmavá), (Rumex hydrolapathum štovík koňský), Polygonum tomentosum - rdesno plstnaté, Ranunculus sardous* pryskyřník sardinský, (Thalictrum lucidum* - žlutucha žlutá ssp. světlá [ž. lesklá]), (Trifolium fragiferum* - jetel jahodnatý), (Lotus siliquosus štírovník přímořský [Tetragonolobus maritimus - ledenec prímořský]), (Lathyrus paluster [L. palustris] - hrachor bahenní), (Euphorbia palustris - pryšec bahenní), (Hypericum acutum* - třezalka čtyřkrí́dlá), (Lythrum virgatum* kyprej prutnatý, Lythrum hyssopifolium - kyprej ysopolistý), (Sium latifolium - sevlák širolistý [s. potoční]), (Cnidium venosum [C.dubium] - jarva žilnatá), (Gratiola officinalis - konitrud lékařský), (Peplis portula - kalužník šruchový), (Centaurium pulchellum - zeměžluč spanilá), (Teucrium scordium ožanka česneková [o. čpavá]), (Scutellaria hastifolia - šišák hrálolistý [š. hrálovitý]), (Leonurus marrubiastrum* - buřina jablečníkovitá), (Mentha aquatica - máta vodní, M. pulegium ${ }^{* *}$ - máta polej), (Lycopus exaltatus* - karabinec statný), Veronica scutellata - rozrazil štítkovitý, (Veronica anagalloides rozrazil bařinný), (Aster tripolium - hvězdnice slanistá), (Pulicaria dysenterica - blešník úplavičný), (Pulicaria vulgaris* - blešník obecný), Bidens cornuus [B. cernua] - dvouzubec nící, Senecio erraticus** - starček bludný, Cirsium canum - pcháč šedý, (Sonchus uliginosus [S. arvensis] - mléč rolní).

\section{RÁKOSINY}

Okraje mělčích, pomalu tekoucích a stojatých vod zarůstalo společenstvo rákosin, tvořené hlavně rákosem obecným (Phragmites australis) - viz obr. 11, orobincem (Typha latifolia a Typha angustifolia), zblochanem vodním (Glyceria maxima) a několika druhy vysokých ostřic (Carex sp. div.). Mezi nimi se občas objevovaly i vysloveně vodní rostliny. Na březích přecházely rákosiny do zazemňovaných oblastí a pronikaly prípadně až do vlhkých luk.

\section{DRUHY PÍSČITÝCH BŘEHŮ DYJE}

(Equisetum ramosissimum - přeslička větevnatá), (Equisetum hiemale [E. hyemale] - přeslička zimní), (Cyperus fuscus* - šáchor hnědý), (Heleocharis [Eleocharis] acicularis - bahnička jehlovitá), Heleocharis [Eleocharis] ovata - bahnička vejčitá, (Carex cyperoides - ostřice šáchorovitá), Juncus compressus - sítina smáčknutá, (Juncus sphaerocarpus* - sítina kulatoplodá), Juncus bufonius - sítina žabí, Polygonum (syn. Persicaria) hydropiper rdesno peprník, Polygonum mitis - rdesno řídkokvěté, Sagina procumbens - úrazník poléhavý [úrazník položený], Herniaria glabra - prütržník lysý, (Myosurus minimus - myší ocásek nejmenší), Potenilla supina - mochna poléhavá, (Melilotus dentatus* - komonice zubatá), Gnaphalium uliginosum protěž močálová [protěž bažinná].

(** panonská květena, *středoevropská květena)

Ze shromážděných údajů je ž̌ejmé, že vybudováním Vranovské přehrady zaniklo v jejím zátopovém území velké množství lokalit chráněných druhů rostlin (obr. 12). Průzkum dna Vranovské a Znojemské přehrady, obnaženého v souvislosti s opravou jejich hrází v roce 2005 přinesl nové zajímavé poznatky o flóře a vegetaci regionu středního Podyjí. Oproti dřívějším údajům je možno zde považovat za běžný výskyt druhư Limosella aquatica, Peplis portula, Cyperus fuscus, Carex bohemica, Eleocharis ovata a Bidens radiata, které byly dosud hodnoceny jako vzácné či řídce se vyskytující [57].

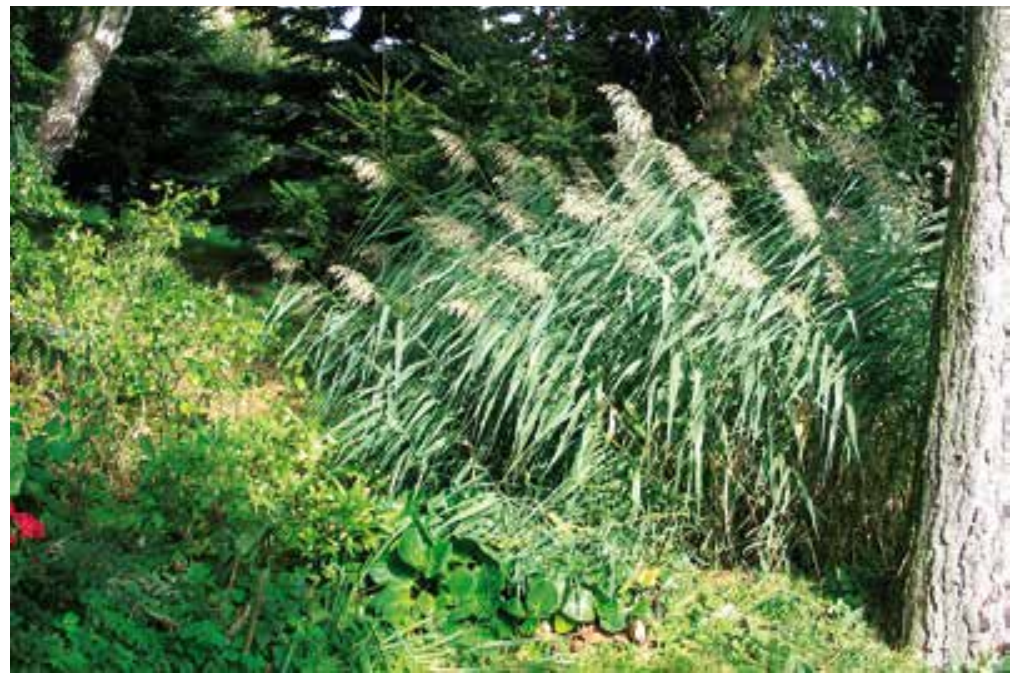

Obr. 11. Rákos obecný Phragmites australis - hojný druh bažinných rostlin v zátopové oblasti Vranovské přehrady pred zatopením

Fig. 11. Phragmites australis - abundant plant species of marshes in floodded area of the Vranov Dam before flooding these wetlands 


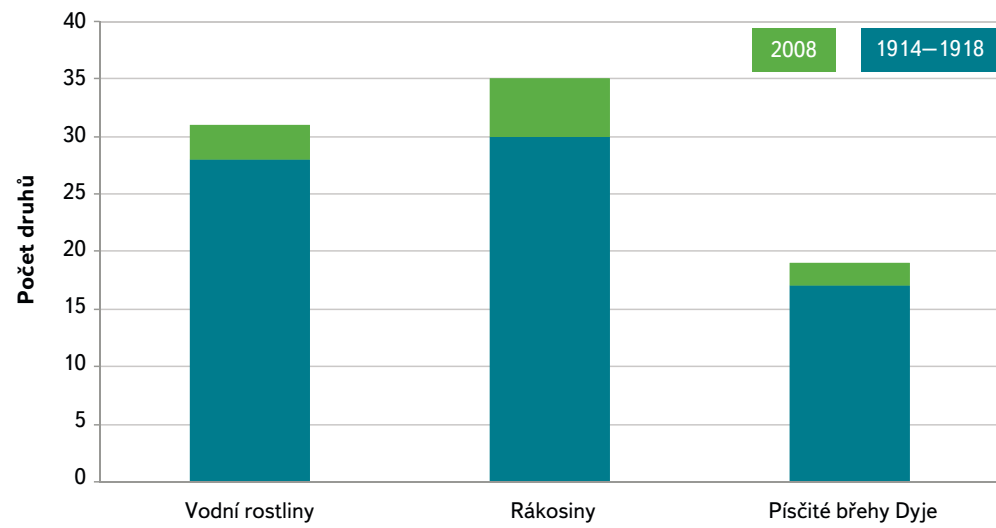

Obr. 12. Zastoupení vyšších vodních a bažinných rostlin v řece Dyji před a po výstavbě Vranovské přehrady (1914-1918 - Himmelbaur a Stumme [24], 2008 - Chytrý a kol. [56]) Fig. 12. Distribution of water and marsh plants in the Dyje River before and after construction of the Vranov Dam (1914-1918 - Himmelbaur and Stumme [24]; 2008 - Chytrý et al. [56])

\section{Vodní dílo Nové Mlýny}

\section{ZMĚNY SPOLEČENSTVA ŘAS A SINIC VE VODË (FYTOPLANKTONU)}

V soustavě Novomlýnských nádrží dochází k silnému pomnožování řas a sinic, přinášených př́tokovou vodou řeky Dyje, ale i přítoků střední nádrže - řek Svratky a Jihlavy. Vytvárí se planktonní společenstvo eutrofních rybníků, které má sice větší počet druhů než Dyje na př́toku a zaniklé přirozené tůně, jde však o běžné druhy $v$ silně úživných vodách. Velká část pomnoženého fytoplanktonu je sice $v$ nádržích eliminována - zčásti se stává potravou zooplanktonu a ryb, zčásti odumírá a zvětšuje na dně množství sedimentu, bohatého na živiny. Na odtoku z dolní nádrže je řeka Dyje významně obohacena o řasy a sinice a také složení společenstva volné vody se podstatně mění. Je to zřejmé z grafického znázornění na obr. 13 a 14. Fytoplankton, namnožený v nádržích, ve vegetačním období negativně ovlivňuje řeku Dyji pod nádržemi.

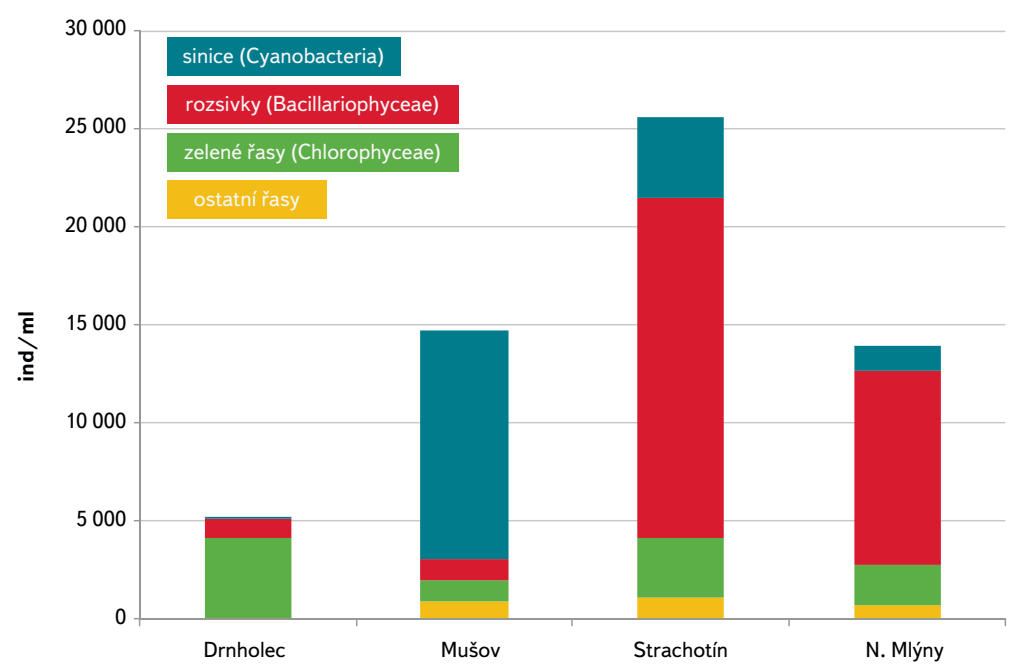

Obr. 13. Změny zastoupení řas a sinic ve vodě (fytoplanktonu) v soustavě Novomlýnských nádrží v době letního vegetačního maxima v roce 1992 (na prítoku - Drnholec a na přelivech tří nádrží: horní - Mušov, střední - Strachotín a dolní - Nové Mlýny) Fig. 13. Distribution of algae and Cyanobacteria (Phytoplankton) in the Nové Mlýny Reservoirs at the vegetation maximum of 1992 (inflow - Drnholec, overflow of the upper basin - Mušov, middle basin - Strachotín and lower basin - Nové Mlýny)

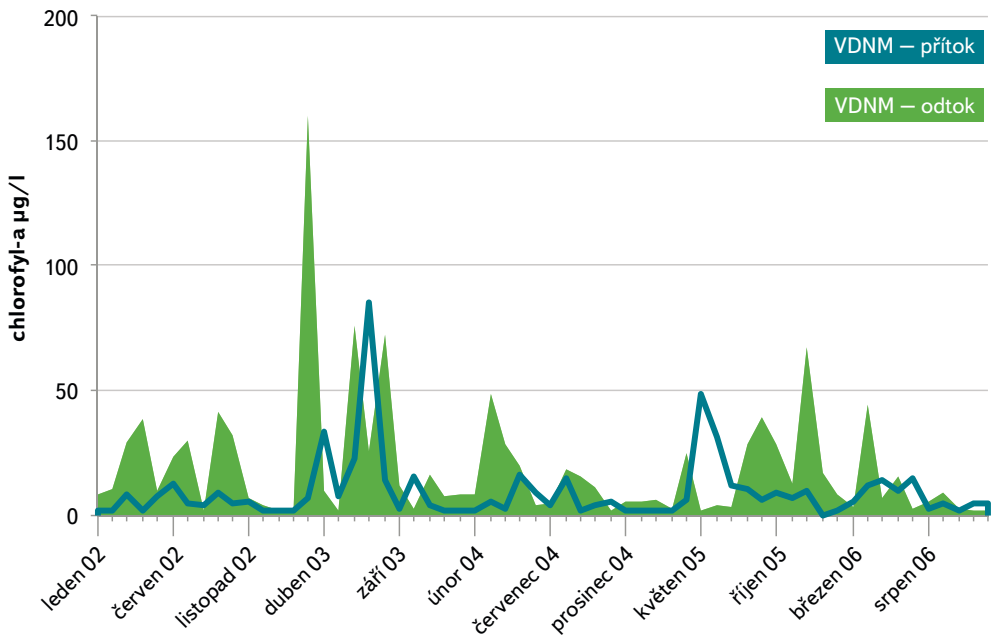

Obr. 14. Změny množství fytoplanktonu (chlorofylu-a) v řece Dyji nad (př́tok Drnholec) a pod (Nové Mlýny) vodním dílem Nové Mlýny v letech 2002-2006

(data: Povodí Moravy Brno)

Fig. 14. Variable abundance of phytoplankton (Chlorophyll-a) in the Dyje River upstream (Drnholec) and downstream (Nové Mlýny) of the Nové Mlýny Water Reservoirs in 2002-2006 (data: Povodí Moravy Brno)

\section{ZMĚNY SPOLEČENSTVA NÁROSTU゚ NA DNĚ (FYTOBENTOSU)}

Složení nárostů na dně a ponořených předmětech (fytobentosu) v řece Dyji bylo sledováno od 50. let minulého století. $V$ tomto období prošla Dyje v úseku mezi ústím rakouského prítoku Pulkavy a dnešním ústím Dyje do Novomlýnských nádrží mnoha kvalitativními změnami.

V letech 1955 až 1959 Dyje v úseku pod ústím Pulkavy byla hodnocena jako mírně znečištěný tok. Dno bylo hustě porostlé vláknitými řasami Cladophora glomerata (žabí vlas), vyššími vodními rostlinami - rdesty (Potamogeton sp.), stolístkem (Myriophyllum sp.), hvězdošem (Callitriche sp.) apod. Ve velkém množství se zde vyskytovala i ruducha Audouinella chalybaea, která je považována za indikátor čistých vod. Nárosty mikroskopických řas tvorily hlavně rozsivky Melosira varians, Diatoma vulgaris, druhy rodů Navicula, Fragilaria, Nitzschia aj. Na dně převládali čistobytní živočichové. Řeka byla vhodná ke koupání. Zlom nastal $v$ podzimním období roku 1959, kdy se čistý tok neuvěritelně změnil k horšímu. Dyje se rázem posunula do kategorie velmi silně znečištěných toků. Hlavní príčinou změn byly odpadní vody z rakouského chemického závodu, přinášené řekou Pulkavou, a odpadní vody z cukrovaru v Hrušovanech, přinášené Jevišovkou, ústící nedaleko současného vzdutí horní novomlýnské nádrže. Ve vodě i na dně převládly indikátory silného organického znečištění vláknité bakterie Sphaerotilus natans, které byly dominantní v období cukrovarnické kampaně i v dalších letech. Mohutné nárosty bakterií, vyskytující se v říčním korytě řeky Dyje v Hevlíně dosáhly postupně několikacentimetrové mocnosti. V květnu 1982 jsme stanovili na ploše $1 \mathrm{~m}^{2}$ dna a kamenitých břehů přibližně 25 kg vláknitých bakterií (obr. 15). Postupně se zvyšovalo množství unášených chomáčů vláknitých bakterií, odpoutaných ode dna spolu s vláknitými sinicemi, které chomáče nadnášely k hladině bublinkami kyslíku, vznikajícího při fotosyntéze. Obrovské množství přinášeného organického znečištění a plovoucích útvarů způsobovalo velmi nepríznivé poměry na konci vzdutí horní nádrže. Ani instalace norné stěny v Dyji na vtoku do nádrže nebyla k záchraně situace dostačující. Nárosty, odpoutané ode dna, tvořily plovoucí „koláče“, které byly posunovány dále do nádrže. Po odumření sinic v zimním období klesaly ke dnu a přispívaly k tvorbě jemného pohyblivého bahna, odčerpávajícího kyslík z vody. Po zprovoznění čistírny odpadních vod v rakouském Pernhofenu a díky postupným změnám $v$ dalších průmyslových závodech došlo k významnému zlepšení stavu [45-50, 58]. 


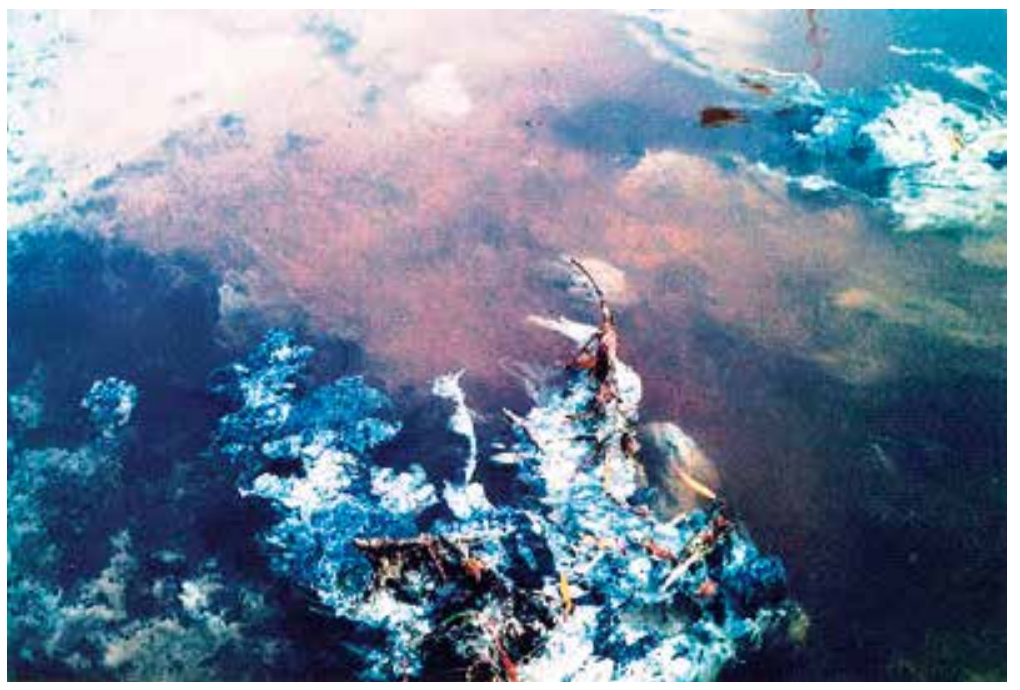

Obr. 15. Bakteriální nárosty v říčním korytě řeky Dyje pod ústím Pulkavy v roce 1982 Fig. 15. Bacterial "Aufwuchs" in the Dyje riverbed downstream of the inflow of the Pulkava River in 1982

V letech 1992-1994 se v Dyji nad horní nádrží v úseku od Hevlína po vtok do nádrže v Drnholci znovu vyskytovaly v nárostech ve větším množství čistobytné druhy - rozsivky Synedra [Fragilaria] ulna a Melosira varians (obr. 16), vláknité rasy Cladophora glomerata, Enteromorpha intestinalis [Ulva intestinalis] a Oedogonium rivulare. Z mechů Amblystegium riparium a Fissidens sp. Pod soustavou nádrží v profilu Nové Mlýny bylo rostlinné společenstvo v korytě Dyje tvořeno hlavně těmito druhy řas: z rozsivek se vyskytovaly ve větším množství Melosira varians, Diatoma vulgaris, Synedra [Fragilaria] ulna, Fragilaria construens, Rhoicosphenia curvata [Rhoicosphenia abbreviata] a Cocconeis placentula, z vláknitých řas Cladophora glomerata, Oedogonium rivulare, Enteromorpha intestinalis [Ulva intestinalis] a dále zelená řasa rodu Tetrasporidium. Z vyšších vodních rostlin Potamogeton crispus a Potamogeton pectinatus (rozbory VúV Brno v rámci zpráv o monitoringu pro Československo-rakouskou komisi hraničních vod - archiv Žáková).

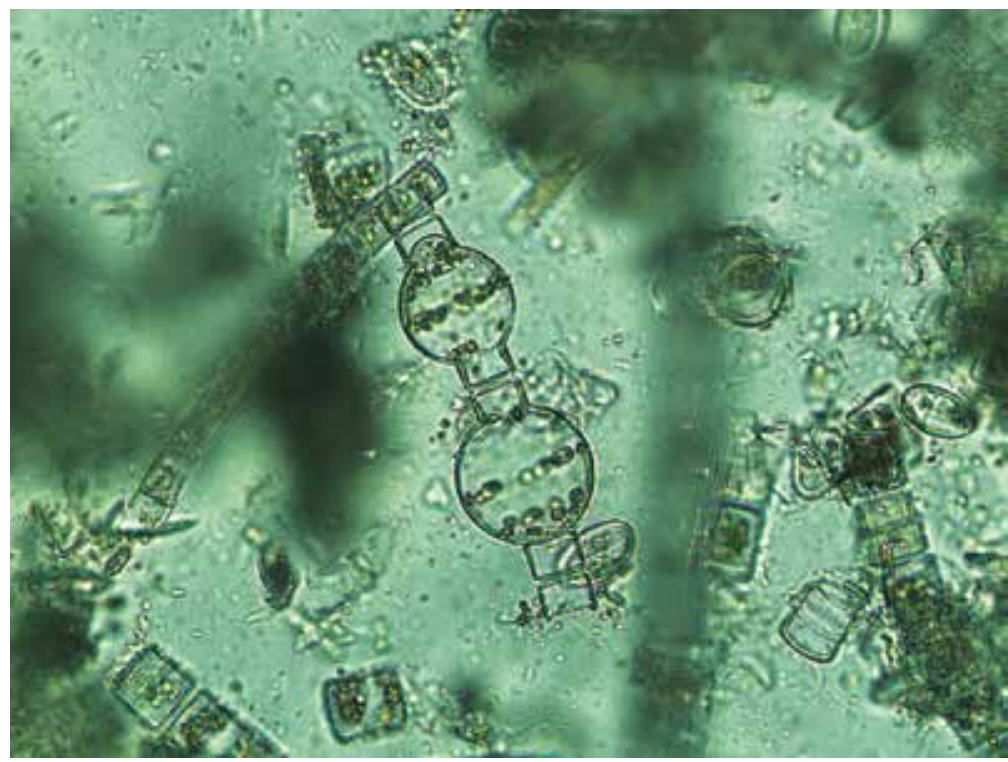

Obr. 16. Melosira varians - typický zástupce nárostových rozsivek v Dyji nad i pod soustavou vodního díla Nové Mlýny (fotografie: P. Sedláček)

Fig. 16. Melosira varians - a typical representant of periphyton diatoms in the Dyje River upstream and downstream of the Nové Mlýny Water Reservoirs (photo: P. Sedláček)

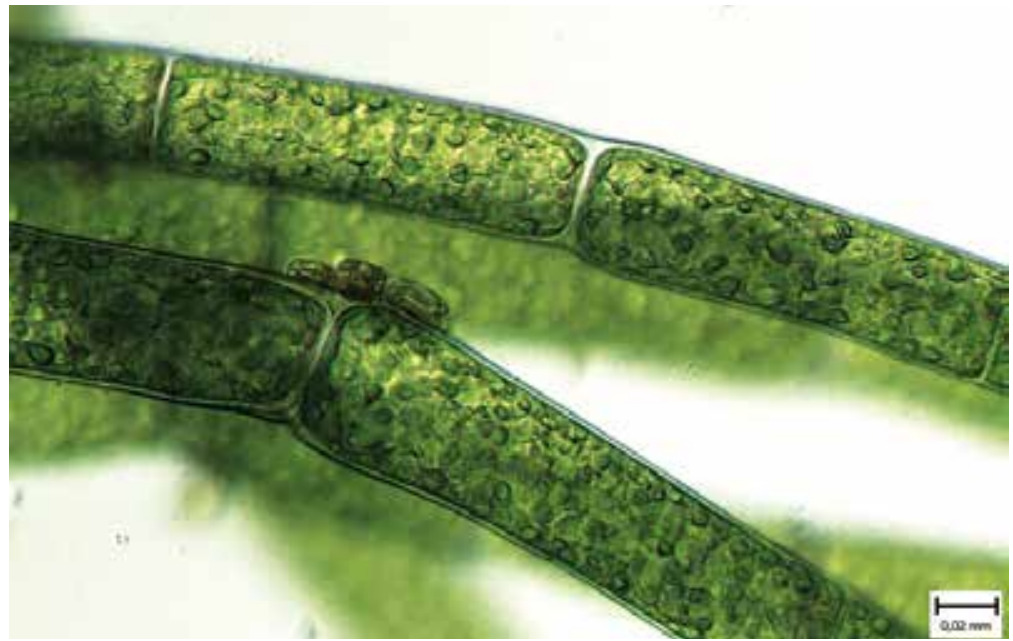

Obr. 17. Cladophora glomerata (Žabí vlas) typický zástupce nárostových vláknitých řas řeky Dyje nad i pod soustavou vodního díla Nové Mlýny (fotografie: P. Sedláček)

Fig. 17. Cladophora glomerata - a representative of filamentous periphyton algae in the Dyje River upstream and downstream of the Nové Mlýny Water Reservoirs (photo: P. Sedláček)

Vlastní tok Dyje se silně zabahněným dnem skýtal před výstavbou nádrží jen lokálně vhodné podmínky pro uchycení řasových nárostů, jejichž rozvoj byl též rušen značným kolísáním hladiny. Výstavbou hrází horní zdrže a soustavy svodných a odvodňovacích príkopů vznikly nové mikrobiotopy pro nárostová epilitická společenstva. Z druhů, dosahujících silnějšího rozvoje uvádějí autoři Ettl, Gardavský a Marvan [44]: Stigeoclonium tenue (AG.) Kütz. sensu lato, Cladophora glomerata (L.) Kütz. (obr. 17), Ulothrix zonata (Web and Mohr) Kütz., Vaucheria spp. a Phormidium autumnale Gom.

$\checkmark$ důsledku výstavby VD Nové Mlýny zanikla i lokalita rozsivky Entomoneis costata, z níz byl tento vzácný druh popsán [59].

Hromadný výskyt vláknitých řas v tůních a mrtvých ramenech je charakteristický průvodní jev období jarních záplav v inundační zóně řeky Dyje. V období jarních záplav se často oblast hromadných výskytů řas (zejména druhư rodu Tribonema (obr. 18) a později i rodu Spirogyra rozšiřovala i na plochy přechodně zatopených lučních porostů. Při dlouhotrvajících záplavách, protažených až do léta (např. v roce 1965), docházelo na ploše několika set hektarů rozlité dyjské vody k hromadnému rozvoji zelené vláknité řasy Cladophora fracta. Postupně se zde vystřídala jarní řasová společenstva. Po opadnutí vody se vytvořily souvislé až přes $1 \mathrm{~cm}$ silné koberce, neprodyšně pokrývající půdu a bránící rozvoji vlastních lučních porostů v celém úseku inundační zóny řeky Dyje od Drnholce až po Podivín [44].

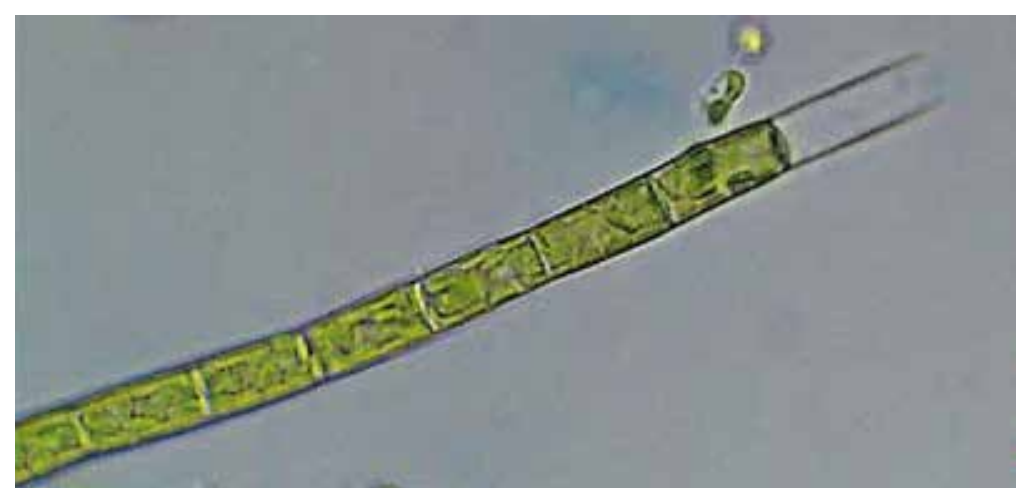

Obr. 18. Vláknitá řasa Tribonema sp. Derbes \& Solier, typický druh hromadně se vyskytující řasy v době jarních záplav před napuštěním vodního díla Nové Mlýny (fotografie: J. Kaštovský) Fig. 18. Tribonema sp. Derbes \& Solier, a typical species with mass occurrence in the period of spring floods before the construction of the Nové Mlýny Water Reservoirs (photo: J. Kaštovský) 
ZMĚNY SPOLEČENSTVA VODNICH A BAŽINNYCH ROSTLIN

V Dyji nad horní nádrží v úseku od Hevlína po vtok do nádrže v Drnholci se v letech 1992-1994 vyskytovaly ve větším množství z vyšších vodních rostlin Batrachium fluitans, Myriophyllum spicatum, Potamogeton crispus, Potamogeton pectinatus, Polygonum amphibium a Callitriche sp. Z mechů Amblystegium riparium a Fissidens sp. Pod soustavou nádrží v profilu Nové Mlýny se z vyšších vodních rostlin hojněji vyskytovaly druhy Potamogeton crispus a Potamogeton pectinatus, podobně jako v Dyji nad nádržemi (rozbory VúV Brno) [58].

Husák $[28,43]$ publikoval přehled významných druhů vodních a bažinných rostlin řeky Dyje v zátopové oblasti Novomlýnských nádrží před jejich napuštěním (horní nádrž [25], střední a dolní nádrž [28]; hojnost na sledovaných lokalitách + až 5, min.-max.). V hranatých závorkách současně používané názvy. Vymizelo velké množství chráněných druhů vodních a bažinných rostlin (zvýraz něny tučně) podle Červeného seznamu cévnatých rostlin České republiky [53]

\section{HORNÍ NÁDRŽ}

VODNÍ ROSTLINY:

Lemna minor (1-4), Lemna gibba (1-5), Lemna trisulca (1-5), Wolffia arrhiza (2-5), Spirodela polyrhiza (1-3), Elodea canadensis (1-5), Nuphar lutea (1-4), Ceratophyllum demersum (1-5), Ceratophyllum submersum (2), Batrachium rionii (3), Callitriche sp. (2), Hydrocharis morsus-ranae (1-5), Potamogeton berchtoldii (5), Potamogeton pectinatus (3), Stratiotes aloides (2).

\section{BAŽINNÉ ROSTLINY:}

Phragmites australis (5), Typha latifolia (4), Glyceria maxima (1-5), Carex riparia (2-5), Carex gracilis (1), Acorus calamus (5), Bolboschoenus compactus [B. maritimus var.compactus] (5), Oenanthe aquatica (1-5), Rorippa amphibia (1-4), Sium Iatifolium (+), Iris pseudacorus (1), Lysimachia vulgaris (1), Galium palustre (1-2), Persicaria amphibia (1), Phalaroides arundinacea (1), Lythrum salicaria (1) (obr.19), Rumex crispus (1), Rumex maritimus (+-3), Rumex hydrolapathum (+-1), Alopecurus aequalis (+-1), Lycopus europeus (1), Stachys palustris (1)

\section{STŘEDNÍ NÁDRŽ}

\section{VODNÍ ROSTLINY:}

Alisma plantago-aquatica (1), Lemnagibba (1), Lemna minor(2), Spirodelapolyrhiza (2), Ceratophyllum demersum (1), Ceratophyllum submersum (4), Nuphar lutea (1-4), Potamogeton pusillus agg. (2), Riccia fluitans (1).

\section{BAŽINNÉ ROSTLINY:}

Acorus calamus (+-4), Bolboschoenus compactus [B.maritimus var.compactus] (1), Galium palustre (1-2), Glyceria maxima (2), Phragmites australis (+-5), Rumex hydrolapathum (+-2), Rumex maritimus (1), Rorippa amphibia (2), Rorippa palustris (3), Limosella aquatica (1), Alisma lanceolatum (1), Lythrum salicaria (1-2), Lysimachia vulgaris (1), Carex hirta (1), Glyceria maxima (4), Carex gracilis (1-2), Carex riparia (2), Sium latifolium (1-2), Oenanthe aquatica (1-5), Butomus umbellatus (1-2), Iris pseudacorus (1-2), Persicaria amphibia (1), Leucojum aestivum (1), Phalaroides arundinacea (1), Stachys palustris (1).

\section{DOLNÍ NÁDRŽ}

\section{VODNÍ ROSTLINY:}

Hottonia palustris (5), Lemna gibba (1), Lemna minor (1), Lemna trisulca (1-2), Ceratophyllum demersum (1-3), Spirodela polyrhiza (1-2), Potamogeton Iucens (5), Potamogeton trichoides (1-2), Nymphaea alba (5), Sagittaria sagittifolia (1), Potamogeton pectinatus (1).
BAŽINNÉ ROSTLINY:

Oenanthe aquatica (1-2), Persicaria amphibia (1), Butomus umbellatus (1), Alisma plantago-aquatica (1), Phragmites australis (1-2), Carex gracilis (2), Carex vesicaria (2), Carex vulpina (2), Phalaris arundinacea (2), Galium palustre (2), Glyceria maxima (2), Leucojum aestivum (2), Lythrum salicaria (1), Iris pseudacorus (1), Bolboschoenus maritimus (1), Eleocharis palustris agg. (1), Lysimachia vulgaris (1), Rorippa amphibia (1), Rumex hydrolapathum (1), Rumex crispus (1), Rumex maritimus (1), Schoenoplectus Iacustris (1), Sium Iatifolium (1), Sparganium emersum (1), Sparganium erectum (1), Typha angustifolia (1), Typha laxmanii (1), Typha latifolia (1).

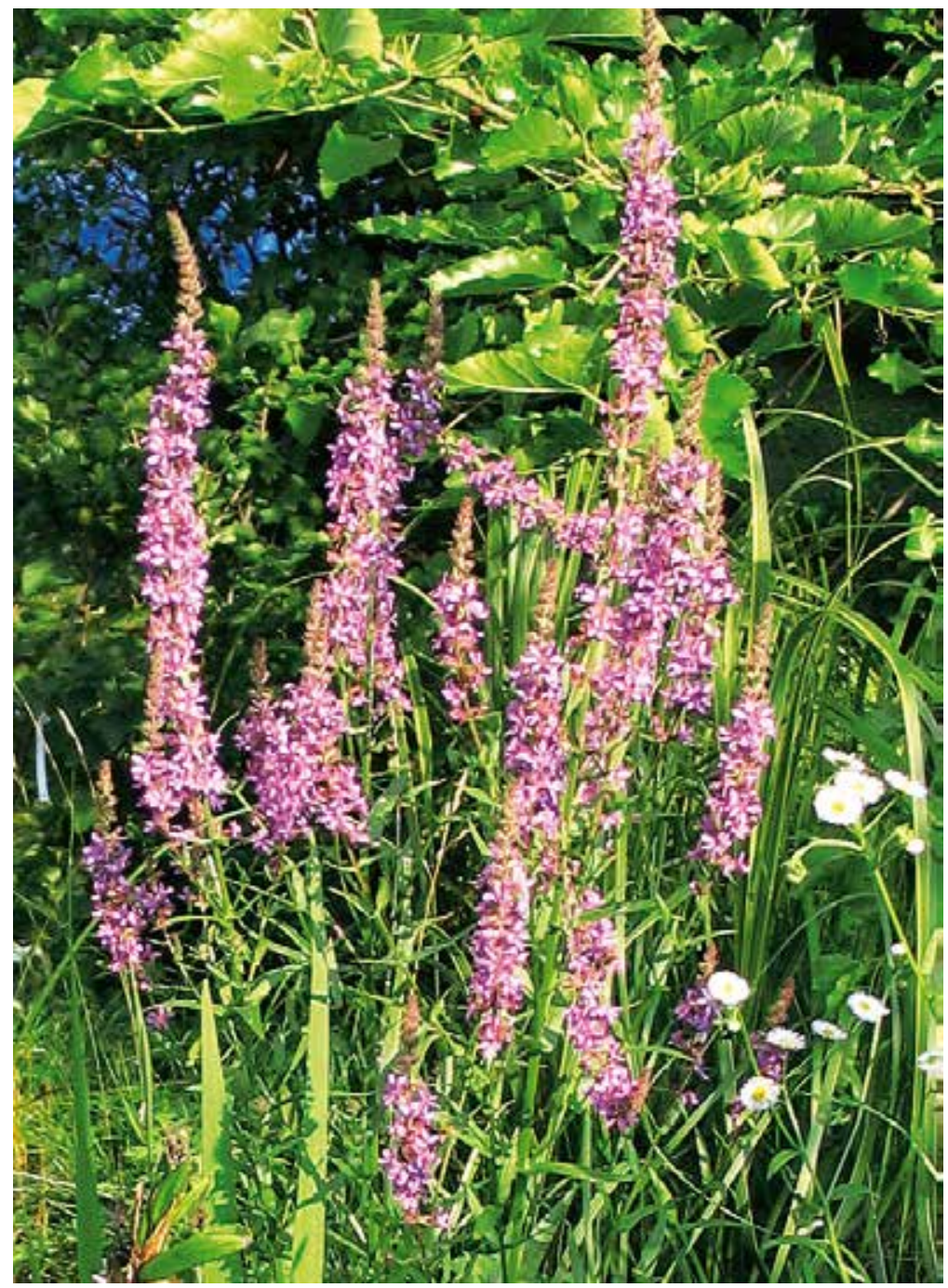

Obr. 19. Kyprej vrbice (Lythrum salicaria) - méně hojný druh bažinných rostlin v zátopovém území vodního díla Nové Mlýny před zatopením

Fig. 19. Lythrum salicaria - less abundant plant species of marshes in floodded area of the Nové Mlýny Water Reservoirs before flooding these wetlands

Zápisy fytocenologických snímků byly prováděny semikvantitativní odhadovou metodou podle Braun-Blanqueta [60].

Již v období schvalování projektů vodohospodářských úprav na jižní Moravě upozorňovali prírodovědci na to, že jejich realizace způsobí velké snížení druhového bohatství prírody v postižené krajině údolních niv Dyje a Moravy.

Poříční nivy kolem dolního toku řeky Dyje byly ještě před 40 lety prostoupeny stovkami drobných vod, které zde vytvořila meandrující a pravidelně se rozlévající řeka. $V$ těchto vodách a $v$ těsné návaznosti na ně vznikala specifická společenstva organismů, výjimečná svou druhovou rozmanitostí. Navíc 
tato krajina, charakteristická svými lužními lesy, loukami a mokřady, měla nejen vysokou ekologickou, ale i estetickou hodnotu. Vodohospodářské zásahy, spojené s regulací dolního toku Dyje (v 60. a 70. letech), výstavbou Novomlýnských nádrží ( $v 70$. a 80. letech), rozoráním téměř poloviny z celkové rozlohy luk, vykácením asi 1300 ha lužního lesa a vysoušením půdy, znamenaly tvrdý zásah do stávajících vyvážených společenstev. Kvantitativní snížení celkového počtu těchto vod však není zdaleka tak citelné, jako úplný zánik (Pansee, Podkovy, Sajlovka, Sand) nebo výrazná degradace některých výjimečných mokřadů (Květné jezero, Kutnar). Zmizely tak lokality charakteristické výskytem vzácných druhů fauny i flóry a zbylé lokality byly navíc zřetelně poškozeny postupující eutrofizací a znečištováním vod. Odstranění přirozených každoročních záplav se pak na biologické diverzitě území projevilo nejsilněji. Zánik většiny periodických tůní s jejich typickou a neopakovatelnou flórou a zejména faunou postihlo druhové bohatství a specifiku této krajiny nejvíce. Kromě pozitivního vlivu přivádění vody z Dyje do lužního lesa pod nádržemi u Nových Mlýnů který v důsledku této stavby přišel o každoroční přirozené záplavy, dochází každým rokem též k masivnímu zavlékání vodního květu sinic do velkého počtu lesních tůní a ohrožení původních společenstev [51].

Ekologové se snažili zachránit některé vzácné druhy rostlin jejich přesazením na vhodná místa mimo zátopu. Ve snaze o zachování genetického materiálu z podmínek aluvia byly přeneseny do nové lokality Betlém rostliny těchto druhư: kosatec dvojbarevný (Iris variegata), leknín bílý (Nymphaea alba), stulík žlutý (Nuphar lutea), řezan pilolistý (Stratiotes aloides) [61]. Po dobu deseti let před napuštěním dolní nádrže probíhalo přesazování velmi vzácné bledule letní Leucojum aestivum (obr. 20), která se v České republice vyskytovala pouze na jižní Moravě na bažinatých loukách a byla zařazena v Červeném seznamu kriticky ohrožených rostlin ČSR. Díky snaze mnoha dobrovolníků z řad ochránců prrírody bylo ze zátopového území zachráněno přes 100 tisíc trsů této bledule a mnoho dalších rostlin - ladoňka vídeňská, kosatec sibiřský aj. [62].

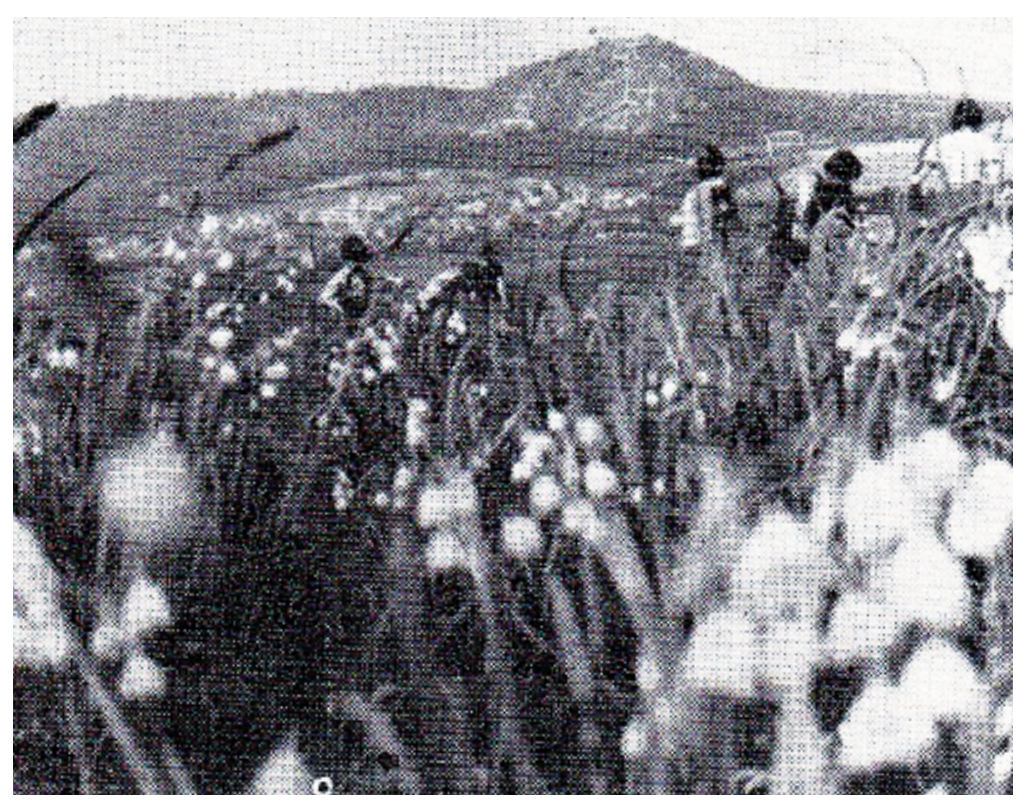

Obr. 20. Bledule letní (Leucojum aestivum), velmi vzácný druh, který se v České republice vyskytoval pouze na jižní Moravě na bažinatých loukách; byla přesazována dobrovolníky na jiné stanoviště před zatopením (fotografie: J. Haluzíková, Veronica č. 3-4, 1988) Fig. 20. Leucojum aestivum - endangered species of marsh plants, occurring in the CR only in South Moravian wetlands; it was transplanted by volunteers to the another suitable site before flooding these wetlands (photo: J. Haluzíková, Veronica No. 3-4, 1988)

\section{ZÁVĚRY}

Projekt Zatopené kulturní a prrírodní dědictví jižní Moravy přinesl cenné poznatky o změnách výskytu společenstev vodních a bažinných rostlin řeky Svratky po vybudování Brněnské přehrady a řeky Dyje po vybudování Vranovské přehrady a vodního díla Nové Mlýny.

Změny množství řas a sinic ve vodě (fytoplanktonu) reky Svratky pod Brněnskou přehradou jsou podmíněny procesy, probíhajícími v nádrži, režimem vypouštění vody, popř. opatřeními, prováděnými $v$ nádrži pro zlepšení jakosti vody (zamezení hromadného výskytu sinicového vodního květu). $\checkmark$ zátopové oblasti Brněnské přehrady byl popsán výskyt více než 50 druhů vodních a bažinných rostlin, které zmizely pod hladinou nádrže. Vyskytoval se zde značný počet ohrožených druhů, které se uvádějí v Červeném seznamu cévnatých rostlin České republiky [53].

Vranovská přehrada, hluboká nádrž korytovitého tvaru, zachycuje téměř úplně přinášený i vyprodukovaný fytoplankton (působí jako účinný lapač fytoplanktonu). Po napuštění Vranovské přehrady se $v$ jejím zátopovém území kromě řas a sinic ve vodě (fytoplanktonu) nezachovala v podstatě žádná společenstva vyšších vodních a bažinných rostlin. Celkem bylo v zátopové oblasti Vranovské přehrady před zatopením popsáno kolem 80 druhů vodních a bažinných rostlin, téměř polovina z nich byly ohrožené druhy.

$\checkmark$ Novomlýnských nádržích se po jejich napuštění vytvořilo bohaté planktonní společenstvo silně úživných (eutrofních) vod, tvořené větším počtem druhů než v Dyji na př́toku a v zaniklých přirozených tůních, jde však o běžné druhy eutrofních vod. Fytoplankton, namnožený v nádržích, ve vegetačním období má negativní vliv na vlastní nádrže i řeku Dyji pod nimi. V zátopové oblasti všech tři Novomlýnských nádrží byl před jejich napuštěním zaznamenán výskyt přes 23 druhů vodních rostlin, z nich 12 druhů ohrožených a 41 druhů bažinných rostlin, z toho 8 druhů ohrožených $[28,43]$.

Naše bádání ukázalo, že v zátopových oblastech všech tří hodnocených nádrží byla výrazně ovlivněna řasová společenstva a zmizela hodnotná společenstva vyšších vodních a bažinných rostlin, tvořená velkým počtem ohrožených druhů - od kriticky ohrožených až po druhy vyžadující zvýšenou ochranu podle Červeného seznamu cévnatých rostlin České republiky [53].

Shromážděné údaje umožňují hodnotit dopady vybudování vodních děl na prírodní prostředí a poskytnout tím podklady pro posuzování dalších projektovaných nádrží u nás i ve světě.

\section{Poděkování}

Děkuji Ing. Pavlu Sedláčkovi, Mgr. Rodanu Gerišovi a doc. RNDr. Janu Kaštovskému, Ph.D., za poskytnutífotografii răas a Mgr. Kateřině Sovové, Ph.D., za úpravy grafü. Dále děkuji prof. RNDr. Milanu Chytrému, Ph.D., a dalším pracovníkům Ústavu botaniky a zoologie Masarykovy university v Brně za poskytnutí staré botanické literatury. Článek vznikl za podpory projektu Programu aplikovaného výzkumu a vývoje národní a kulturní identity (NAKI) Ministerstva kultury ČR (DF13P01OVV012).

\section{Literatura}

[1] MLEJNKOVÁ, H. Zatopené kulturni a prírodni dědictví jižni Moravy. Brno: VúV TGM, 2016, 264 s. ISBN 978-80-87402-52-8.

[2] ŽÁKOVÁ, Z. a SEDLÁČEK, P. Jak brněnská přehrada ovlivnila společenstva vodních a bažinných rostlin? In: MLEJNKOVÁ, H. a kol. Zatopené kulturni a prírodni dědictvíjižní Moravy. Brno: VúV TGM, 2016, s.118-123. ISBN 978-80-87402.

[3] NAVE, J. Algen Mährens und Schleziens. Verh. d. naturf. Ver. in Brünn, 1863, 2, s. 17-58.

[4] MAKOWSKI A.: Die Flora des Brünner Kreises nach pflanzengeographischen Prinzipien. Ver. Naturforsch. Ver., Brünn 1, 1863, p. 45-210.

[5] FISCHER, R. Die Algen Mährens und ihre Verbreitung. Verh. d. nat. Vereins in Brünn, Brno, 1920, 57, p. 1-94. 
[6] BíLÝ, J. Příspěvek ku květeně moravských rozsivek. Sbor. Přirodov. Klubu v Brnĕ, 1925, 8, s. 122-135.

[7] NOVÁČEK, F. Příspěvek k oekologii Aphanizomenon flos aquae, Microcystis aeruginosa, Anabaena flos aquae. Práce Moravskoslezské prírodov. spol,1935, sv. IX, 9, s. 1-23.

[8] ROČEK, J. O čistotu povrchových vod. Hygienická studie na ř. Svitavě a Svratce. Spisy lék. fak. M.U. $\checkmark$ Brně Xi. 6. Sign. A 114, 1931.

[9] RZEHAK, A. Ergebnisse der mikroskopschen Untersuchung des Trinkwassers der Stadt Brünn. Jahrb. d. deutsch. Comm. Oberschule in Brünn, 1886,1885/86, p. 1-26.

[10] LHOTSKÝ, O a ROSA, K. Soupis Moravskoslezských sinic a řas. Praha: Nakladatelství Československé akademie věd, 1955, $260 \mathrm{~s}$.

[11] HRUBY, J. Botanischer Führer durch Brünn and Umgebung. Brno, Czerny, 1928, 192 s.

[12] LOSOSOVÁ, Z. a kol. Květena Brna - současný stav poznání. Živa. Academia SSČ AVČR, 2015, 6, s. 291-292.

[13] GERIŠ, R. Struktura fytoplanktonu ve VN Brno v letech 2010-2012. In: Kosour, D. (ed.): Vodnínádrže 2015, PM, Brno, 2015, poster.

[14] GERIŠ, R. a KOSOUR, D. Vývoj biomasy fytoplanktonu Brněnské údolní nádrže v letech 2004-2013. In: Kosour, D. (ed.) Vodní nádrže 2013, PM, Brno, 2013, s. 121-126.

[15] MARVAN, P., MARŠALEK, B., and POKORNÝ, J. Analysis of factors responsible for the mass development of Microcystis aeruginosa in the Brno dam-reservoir and in the subsequent reach of the Svratka River. In: KNOPPOVÁ, J. (ed.) Report 1991-1992, Třeboň: Inst. Botany, 1992, s. 71.

[16] ŽÁKOVÁ, Z. Brněnská nádrž, zhodnocení rozvoje fytoplanktonu v roce 1993. Výzkumná zpráva. BIOTES Brno, 1993, $23 \mathrm{~s}$.

[17] ŽÁKOVÁ, Z. Změny rostlinných společenstev v řece Dyji po vybudování vodních nádrží Vranov a Nové Mlýny. In: Štiková, K., Pithart, D. Ř́ční krajina 10. Brno 2014. Koalice pro řeky, 2014, s. 128-134. ISBN 978-80-260-7099-3.

[18] ŽÁKOVÁ, Z. Jak ovlivnilo vybudování nádrži Vranov nad Dyjí a Nové Mlýny rostlinná společenstva v řece Dyji?. In: Svoboda, M. XXXII. Mikulovské sympozium "Voda v dějinách Moravy". Člověk a voda $v$ dějinách: život - prostředí - technika - každodennost - rituály. Mikulov 2014. Břeclav: Muzejní a vlastivědná společnost v Brně, 2015, s. 390-406. ISBN 978-80-86931-99-4.

[19] ŽÁKOVÁ, Z. a SEDLÁČEK, P. Jak Vranovská přehrada ovlivnila společenstva vodních a bažinných rostlin? In: MLEJNKOVÁ, H. a kol. Zatopené kulturni a př́rodní dědictvíjižní Moravy. Brno: Výzkumný ústav vodohospodářský T. G. Masaryka, 2016 a, s. 66-73, ISBN 978-80-87402.

[20] NIESSL, G. Über die Flora der Eisleithen bei Frain und neue Funde. Verhandl. der naturf. Ver. in Brünn, 1867, 6. Cit. Himmelbaur, W., Stumme, E., 1923.

[21] REISSECK, S. Beiträge zur Flora Mährens. Flora 24, 2 Bd., Regensburg, 1841. Cit. Himmelbaur, W., Stumme, E, 1923 .

[22] OBORNY, A. Die Flora der Znaimer Kreises. - Verh. Naturforsch. Ver. Brünn, 1879, 17: p. 105-304. Cit. Himmelbaur, W., Stumme, E, 1923.

[23] OBORNY A. Flora von Mähren und österr. Schlesien. Teile 1-4. Verh. Naturforsch. Ver. Brünn, 1883-1886: 21 (1882): 1-268, 1883; 22 (1883): 269-636, 1884; 23 (1884): 637-888, 1885; 24 (1885): 889-1285, 1886. Cit. Husák, 1984.

[24] HIMMELBAUR, W. and STUMME E. Die Vegetationsverhältnisse von Retz und Znaim. Abh. Zool.bot. Ges. Wien, 1923, vol. 14, No. 2, p. 1-146.

[25] KOČKOVÁ, E. a kol. Zabezpečení trvale př́znivého stavu jakosti vody pro zachování přirozených biocenóz a krajinotvorné hodnoty řeky Dyje $\vee$ oblasti mezinárodního prírodního parku PodyjíThayatal. Závérečná zpráva projektu 1227/93, Vúv Brno, 1994, 64 s.

[26] KOČKOVÁ, E., MLEJNKOVÁ, H. a ŽÁKOVÁ, Z. Kvalita vody v řece Dyji v oblasti národního parku Podyjí. Thayensia, 2001, 4, s. 223-226.

[27] ŽÁKOVÁ, Z. a SEDLÁČEK, P. Změny rasové flóry, vodních a bažinných rostlin reky Dyje po vybudování vodního díla Nové Mlýny, In: MLEJNKOVÁ, H. a kol. Zatopené kulturni a prírodní dédictví jižni Moravy. Brno: VúV TGM, 2016, s. 199-207. ISBN 978-80-87402.

[28] HUSÁK, Š. Sukcese vegetace v systému Novomlýnských nádrží na jižní Moravě. In: Pellantová, J., Franek, M. (eds.) Výzkum vobl. Novoml. nádržív období 1988-1993, ČúOP Brno, 1994, s. 86-100.

[29] HETEŠA, J., HUSÁK, Š. a SUKOP, I. Bibliografie zájmového území. In: Heteša, J., Marvan, P. Biologie nově napuštěné nádrže. Studie ČSAV 3.84, Academia Praha, 1984: vyd. 1., s. 169-175.

[30] ROHRER, R. and MAYER, A. Vorarbeiten zu einer Flora des Mährischen Gouvernements. Brünn, 1835. Cit. Husák, 1984.

[31] FORMÁNEK, E. Květena Moravy a rakouského Slezska, Praha, I. - 1887, Brno, Il. - 1892, s. 1. Cit. Husák. 1984.

[32] PODPĚRA, J. Květena Moravy ve vztazích systematických a geobotanických. Část soust., sv. I Práce Mor. prírod. společ. Brno, 1924, sv. I., sp. 10, sign F 10: s. 393-618 (1-226). Cit. Husák, 1984.

[33] DOSTÁL, J. Květena ČSR. Praha, 1948-1950. Cit. Husák 1984.

[34] FRÖLICH, A. Über das Vorkommen einiger Pflanzen in S.-Mähren. Verh.Nat.Ver. Brünn, 1935, 66, 1-4. Cit. Husák, Š. 1984.

[35] ŠUK, V. Květena Mikulovska. ONV Mikulov, 1954, 139 s. Cit. Husák, 1984.

[36] ZAPLETÁLEK, J. Geobotanické poznámky z dolního Podyjí. Sborn.klubu prírod, Brno, 1939, 21, s. 61-68. Cit. Husák, 1984.
[37] SLAVOŇOVSKÝ, F. Příspěvek k poznání květeny jižní Moravy. II. Louky u Drnholce. Spisy prírod. Fak. Masaryk. Univ. Brno, 1954, 357, ser. L 9, s. 319-348.

[38] VICHEREK, J. Poznámky k vegetaci a květeně aluviální nivy dolního Podyjí. Sborn. Klubu prírod. Brno, 1960, 32, s. 55-67. Cit. Husák, 1984.

[39] ŠEDA, Z. Studie prognozy zarůstání údolní nádrže na Dyji u Nových Mlýnů. Katedra botaniky MU Brno, 1967, 44 s.

[40] BALÁTOVÁ-TULÁČKOVÁ, E. Beitrag zur Kenntnis der tschechoslowakischen Cnidion venosi Wiesen. Vegetatio. 1969, 17, s. 200-207.

[41] FIALA, K. Poznámky k rozšírení vodních makrofyt v aluviální nivě dolního Podyjí. Zpr. Čs. bot. společ., Praha, 1, s. 153-158. Cit. Husák 1984.

[42] FRÖLICH, A. Über das Vorkommen einiger Pflanzen in S.Mähren. Verh.Nat.Ver. Brünn, 64, 1933, p. 32-33. Cit. Husák, 1984

[43] HUSÁK, Š. Zhodnocení stavu vegetačního krytu zájmového území pred napuštěním nádrže. In: Heteša, J., Marvan, P. (eds) Biologie nově napuštěné nádrže. Studie ČSAV 3.84, Academia Praha, 1984, vyd. 1., s. 85-93.

[44] NOVOTNÝ, V. a KOČKOVÁ, E. Prognóza jakosti vody v nádrži Nové Mlýny. Výzkumná zpráva VúV Brno. Brno: VÚV TGM, 1967,148 s.

[45] NOVOTNÝ, V. a KOČKOVÁ, E. Prognóza jakosti vody v nádrži Nové Mlýny. Závěrečná zpráva Vúv Brno. Brno: VÚV TGM, 1970, $146 \mathrm{~s}$.

[46] KOČKOVÁ, E. a kol. Výsledky šetření v oblasti vodního díla Nové Mlýny za rok 1975, Výzkumná zpráva VúV Brno, 1976, $28 \mathrm{~s}$.

[47] KOČKOVÁ, E. a kol. Výsledky šetření v oblasti vodního díla Nové Mlýny za rok 1976, Výzkumná zpráva VúV Brno, 1977, $44 \mathrm{~s}$.

[48] KOČKOVÁ, E. a kol. Výzkum vlivu fyzikálních faktorů a rozkladných procesů ve vodě a sedimentech na kvalitu významných toků a nádrží v povodí Moravy. Část. 2: Vodní dílo Nové Mlýny. Výzkumná zpráva VÚV Brno, 1991, $130 \mathrm{~s}$

[49] ŽÁKOVÁ, Z., KOČKOVÁ, E., and MLEJNKOVÁ, H. Development of biological and chemical conditions in Nové Mlýny reservoirs. In: Book of abstracts of the $5^{\text {th }}$ Intern. Conf. on Reservoir Limnology and Water Quality, Brno 2006, Inst. of Botany. Průhonice: Acad. of Science CR, 1. vol., 2006, p. 272-275.

[50] ETTL, H., GARDAVSKÝ A., MARVAN, P. Rozvoj vláknitých ras $\vee$ horní zdrži, svodných a odvodňovacích př́kopech. In: Heteša, J., Marvan, P. Biologie nově napuštěné nádrže. Studie ČSAV 3.84, Academia Praha, 1984, vyd. 1., s. 77-84.

[51] HETEŠA, J., MARVAN, P., SKÁCELOVÁ, O. a KOPP, R. Řasy a sinice mokřadů dolního Podyjí. Forestalia 23, Kostelec nad Černými lesy, 2012,168 s.

[52] MORONGA, J., SLÁDEK, R. a PALČĆK, J. Realizace opatření na brněnské údolní nádrži. In: Kosour, D. (ed.) Vodnínádrže 2013, PM, Brno, 2013, s. 109-112.

[53] GRULICH, V. a kol. Červený seznam cévnatých rostlin České republiky, 2012. Dosptupné z: www.botany.cz/cs/cerveny-seznam.

[54] KUBÁT, K. a kol. (eds) Klíč ke květeně České republiky. Praha: Academia, 2002, 927 s.

[55] KOMÁREK, O. and MARVAN, P. The influence of the Vranov Reservoir hydropower station operation on phytobenthos in the Dyje River (Czech Republic). Folia Fac. Sci. natur. Univ. Masarykianae Brunensis, Biologia 102, 1999.

[56] CHYTRÝ, M., GRULICH, V., and ANTONÍN, V. Podyjí National Park Botanical Excursion Guide. Brno: Department of Botany and Zoology Masaryk University, 2008, 19 p.

[57] BRAVENCOVÁ, L., MUSIL, Z. a REITER, A. Flóra a vegetace obnaženého dna Znojemské a Vranovské údolní nádrže (střední Podyjí) (Flora and Vegetation of Exposed Bottom of the Znojmo and Vranov Water Reservoirs (Middle Dyje Basin). Thayensia, 2007, 7, s. 153-173. ISSN 1212-3560.

[58] KOČKOVÁ, E., ŽÁKOVÁ, Z. a MLEJNKOVÁ, H. Řeka Dyje v Drnholci a její význam pro vodní dílo Nové Mlýny, In: KORDIOVSKY, E. et al. Drnholec. Muzejní a vlastivědná společnost, 2011, s. 33-45.

[59] BíLÝ, J. Třetí příspěvek k poznání květeny moravských rozsivek. Sborn. Klubu př́rod. Brno, 1930, 12, s. 1-32. [60] KUBÍKOVÁ, J. Geobotanické praktikum. SPN Praha, 1970, 186 s.

[61] ŠEBELA, M. Betlém naděje lužní krajiny, 1. vydání, Moravské zemské muzeum Brno a Veronica ZO ČSOP,1994, 24 s., ISBN 80-7028- 033-6.

[62] BUČEK, A. Akce Dno naposledy. Veronica, 1988, roč. 2, č. 3-4, s. 4.

Autor

RNDr. Zdeňka Žáková, CSc.

冈zakova@biotes.com

BIOTES

Přispěvek prošel lektorským řizením. 


\section{HOW CONSTRUCTION OF WATER RESERVOIRS IN SOUTH MORAVIA AFFECTED COMMUNITIES OF AQUATIC AND WETLAND PLANTS}

ZAKOVA, Z.

BIOTES

Keywords: communities of aquatic and marsh plants flooded area of reservoirs - Brno Dam - Vranov nad Dyje Dam Nové Mlýny system of reservoirs

Within the project "Submerged cultural and natural heritage of South Moravia" a large amount of data was collected on the composition of aquatic and marsh plant communities in the Svratka and Dyje/Thaya Rivers before building reservoirs on these rivers. Evaluation of the obtained data confirmed that plant communities found in the Svratka and Dyje/Thaya River floodplains and below the water reservoirs were strongly influenced by the construction of dams of Brno (1935-1940), Vranov (1930-1933), as well as the system of the Nové Mlýny reservoirs (1975-1988). The study was based on a comparison between older floristic evidence with the state of the respective flora in the recent period. Regarding the Nové Mlýny area, the study is based on the results of intensive floristic research conducted before construction of these reservoirs. Algal communities were monitored within the framework of projects of the T. G. Masaryk Water Research Institute in Brno (Brno Dam 1985, 1992-1993, Vranov Dam after 1988 and Nové Mlýny Water Reservoirs after 1950) and of projects implemented by other institutions - Povodí Moravy Brno, Institute of Botany AS CR at Třeboň etc. 